Madrygal. Revista de Estudios Gallegos

ISSN: 1138-9664

\title{
De subenca a ba fenecer. Reclamando o catastro de Ensenada para o estudo do galego moderno
}

\author{
Guillermo Vidal Fonseca ${ }^{1}$
}

Recibido: 19 de agosto de 2020 / Aceptado: 30 de outubro de 2020

Resumo. Os estudos de lingüística histórica galega enfrontaron, de sempre, dificultades para as súas pescudas sobre o galego da Idade Moderna debido á escaseza ou menor proliferación de fontes escritas nesta lingua durante o período en comparación cos precedentes ou subseguintes. A través do estudo de varios documentos do catastro de Ensenada, elaborado en castelán no século XVIII, relativos á comarca galega de Barcala, identificamos mediante unha exhaustiva investigación individualizada máis de medio cento de voces ou construcións netamente galegas -ou afectadas por fenómenos típicos do galego da época- que analizamos detalladamente en diferentes planos gramaticais: o fonético, o morfolóxico, o sintáctico, o léxico e o semántico. O estudo desas interferencias da lingua galega no castelán dos textos permite achegármonos a diferentes características do galego medio, particularmente do falado nesa comarca do occidente galego e, mediante esa contribución, o artigo pretende poñer en valor e reclamar unha necesidade aínda non explotada: a de valerse do catastro de Ensenada como fonte documental indirecta para estudar o galego moderno, malia estar escrita en castelán.

Palabras chave: galego; lingüística histórica; Idade Moderna; catastro de Ensenada.

\section{[es] De subenca a ba fenecer. Reclamando el catastro de Ensenada para el estudio del gallego moderno}

Resumen. Los estudios de lingüística histórica gallega se han enfrentado, desde siempre, a dificultades en sus investigaciones sobre el gallego de la Edad Moderna debido a la escasez o menor proliferación de fuentes escritas en esta lengua durante el período en comparación con los precedentes o subsiguientes. A través del estudio de varios documentos del catastro de Ensenada, elaborado en castellano en el siglo XVIII, relativos a la comarca gallega de Barcala, identificamos mediante una exhaustiva investigación individualizada más de medio centenar de voces o construcciones netamente gallegas -o afectadas por fenómenos típicos del gallego de la época- que analizamos detalladamente en diferentes planos gramaticales: el fonético, el morfológico, el sintáctico, el léxico y el semántico. El estudio de esas interferencias de la lengua gallega en el castellano de los textos nos permite acercarnos a diferentes características del gallego medio, particularmente del hablado en esa comarca del occidente gallego y, mediante esa contribución, el artículo pretende poner en valor y reclamar una necesidad aún no explotada: la de valerse del catastro de Ensenada como fuente documental indirecta para estudiar el gallego moderno, pese a estar escrita en castellano.

Palabras clave: gallego; lingüística histórica; Edad Moderna; catastro de Ensenada.

\section{[en] From subenca to ba fenecer. Demanding Ensenada's Cadastre for the Study of Modern Galician Language}

\begin{abstract}
The studies of Galician historical linguistic always faced difficulties for their investigations on early modern period Galician language due to the shortage or less proliferation of written sources in this language during this period in comparison with the previous or the subsequent ones. Through the study of several documents about Ensenada's Cadastre, developed in Spanish on the 18th century, concerning the Galician region of Barcala, we identify through an exhaustive personalised investigation more than half a hundred voices or constructions clearly Galician -or affected by typical phenomena of the Galician of that era- that we analyse in detail in different grammatical levels: phonetic, morphologic, syntactic, lexical and semantic. The study of those interferences of Galician language in Spanish language in texts, allows us to approach different characteristics of average Galician, particularly the one spoken in that western Galician region and, through that contribution, the article expects to claim and to point out the value of a necessity still
\end{abstract}

1 Universidad de Extremadura. Departamento de Lenguas Modernas y Literaturas Comparadas.

Correo-e: gvidalfonseca@unex.es. ORCID: https://orcid.org/0000-0003-3494-3405. 
unexploited: to take advantage of Ensenada's Cadastre as an indirect documental source to study modern Galician language, in spite of being written in Spanish.

Keywords: Galician Language; Historical Linguistic; Early Modern Period; Ensenada's Cadastre.

Sumario. 1. Introdución e obxectivos. 2. O catastro de Ensenada. 2.1. O catastro como fonte directa nas ciencias sociais. 2.2. Corpus seleccionado. 3. Galeguismos nos textos e a súa tipoloxía. 3.1. Galeguismos fonéticos. 3.1.1. Alteración do vocalismo átono. 3.1.2. Seseo. 3.1.3. Despalatalización. 3.1.4. Outros fenómenos consonánticos. 3.2. Galeguismos morfolóxicos. 3.3. Galeguismos sintácticos. 3.3.1. Perífrase ir + infinitivo. 3.3.2. Verbo transitivo + $\mathrm{CD}$ humano 3.4. Galeguismos léxicos. 3.5. Galeguismos semánticos. 4. Conclusións. 5. Referencias bibliográficas.

Como citar: Vidal Fonseca, G. (2021): "De subenca a ba fenecer. Reclamando o catastro de Ensenada para o estudo do galego moderno", en Madrygal. Revista de Estudios Gallegos 24, pp. 217-238, DOI: http://dx.doi.org/10.5209/ madr. 80241.

\section{Introdución e obxectivos}

Durante os séculos comprendidos entre o XVI e o XIX, e por motivos políticos, a lingua galega sufriu un proceso satelizador por parte do castelán que o privou de funcións que ata ese momento exercía. O proceso, amplamente documentado e tratado desde hai tempo nos estudos de lingüística histórica e sociolingüística galega $^{2}$, trouxo unha importante consecuencia para esta lingua que Monteagudo (2020: 75115) resume así:

Durante o século XV a hexemonía do castelán afiánzase ata o punto de que a finais do mesmo acaba suplantando o galego como lingua literaria e instrumental, do notariado e de distintas institucións (concellos, gremios, cabidos, mosteiros, igrexas...) (...). Baixo a presión combinada da corte real, que sateliza o groso da aristocracia galega, do novo aparato de Estado implantado en Galicia desde os Reis Católicos e da dependencia cada vez máis estreita da Igrexa galega respecto de Castela, contra a metade do século XVI o galego era xa unha lingua case completamente ágrafa. (Ibid.: 77)

Esta case expulsión do galego do plano gráfico, ben na documentación, ben na creación artística literaria, é o que se deu en coñecer de xeito estendido en ámbitos educativos e historiográficos relacionados coa nosa lingua, desde a segunda metade do século XX, como Séculos
Escuros (Monteagudo 2016: 149-179). A característica principal desta etapa, no que concirne á lingüística histórica galega especializada na pescuda dos trazos da lingua durante a Idade Moderna, é a penuria de medios para realizar ese labor, pois, como indica Mariño Paz (2017: 90-95), existe unha "drástica e descomunal redución no relativo á cantidade de textos" dos séculos XVI-XVIII dos que se pode tirar proveito para esa empresa. Pola contra, os textos en castelán desa época en Galiza son "abundantísimos. (...) As posibilidades que este tipo de fontes ofrecen para o estudo do galego da época saltan á vista" (Ibid.: 9095) polas grandes interferencias do galego no castelán de Galiza. O mesmo autor móstrase contundente nesta cuestión con anterioridade; sobre a metodoloxía á hora de estudar os cambios lingüísticos desa época, argumenta:

Deberíase analiza-lo peculiar castelán en que están escrit[o]s (...) moitos documentos da época que hoxe en día se poden consultar maiormente en diversos arquivos ou, máis raramente, en edicións modernas. Galeguismos de todo tipo afloran continuamente en textos que, por causa da mentalidade lingüística que desde o século XVI triunfou entre as elites civís e eclesiásticas de Galicia, escribiron en castelán. (Mariño Paz 1998: 265)

A pesar das posibilidades das referidas fontes, en Galiza "es excepcional la edición (...) de fuentes documentales para la época moderna, lo cual explica el déficit bibliográfico que caracteriza la investigación sobre el castellano de Galicia de ese periodo" (Tabernero, Pichel e Enrique-Arias 2020: 182). Esta excepcionalidade provoca que a transferencia galega no castelán de Galiza "ha(ya) sido tradicionalmente un ámbito de estudio muy escasamente abordado para las etapas medieval y moderna, a diferencia de lo que ocurre con la situación del contacto lingüístico en el periodo contemporáneo" (Ibid.: 181).

Así pois, e en base ao razoado, son obxectivos do noso traballo demostrar a validez e a operatividade dunha fonte documental como o catastro de Ensenada (século XVIII), escrita en castelán, para a investigación sobre diferentes trazos do galego medio. Para tal fin, ofrecemos unha breve caracterización da fonte, o seu contexto e a súa natureza lingüística, que servirán logo para mergullarnos en diferentes textos do 
propio catastro a través dos cales recuperamos unha importante mostra de galeguismos, expostos e analizados con detalle na epígrafe 3 , cuxo fin último é o de reclamar a fonte para o devandito coñecemento do galego nos séculos da Idade Moderna.

\section{2. $O$ catastro de Ensenada}

O catastro de Ensenada, censo de bens impulsado na Coroa de Castela no século XVIII e de vital importancia para a historiografía actual nas súas pescudas sobre a Idade Moderna, constitúe unha fonte de coñecementos (en castelán) fundamental sobre o ámbito local da devandita época. Os seus documentos principais son os interrogatorios, escritos a man entre 1749 e 1759 e cuxas copias se custodian no Archivo General de Simancas. Cada interrogatorio do catastro está composto de 40 preguntas que a veciñanza, segundo o establecido nas bases que o regulaban, debía responder: nome do lugar (pregunta 1); xurisdición (2); extensión e límites (3); tipos de terras $(4,5)$; árbores $(6$, 7, 8 e 13); medidas de superficie e capacidade que se usan $(9,10)$; especies, cantidade e valor dos froitos (11, 12, 14 e 16); diezmos e primicias (15); minas, salinas, muíños e outros "artefactos" (17); gando (18, 19 e 20); censo de poboación, con veciños, xornaleiros, pobres de solemnidade $(21,35$ e 36$)$, censo de clérigos (38) e conventos (39); casas e outros edificios (22); bens propios do común (23), sisas e arbitrios (24), gastos do común, como salarios, festas, empedrados, fontes (25), impostos (26 e 27); actividades industriais e comerciais, coa utilidade dos bens ou servizos producidos: tabernas, mesóns, tendas, panaderías, carnicerías, pontes, barcas sobre ríos, mercados e feiras (29), hospitais (30), cambistas e mercadores (31), tendeiros, médicos, cirurxiáns, boticarios, escribáns, arrieiros etc. (32); albaneis, albeites, canteiros, ferreiros, zapateiros etc. $(33,34)$; embarcacións $(37)$; bens alleados (28) e rendas propias do Rei (40) (PARES). O feito de que os escribáns tivesen que redactar exhaustivamente sobre as particularidades locais de cada unha destas cuestións converte a fonte, a priori, nun medio adecuado para a observación e a análise da lingua en calquera dos seus niveis gramaticais; máis, se cabe, cando a lingua da maioría da veciñanza era diferente da lingua empregada na redacción dos documentos (Saavedra 2011: 685-704).

Á par dos Interrogatorios ou Respuestas Generales, que son os documentos polo xeral máis extensos, existen outros documentos catastrais relevantes e que constitúen as Respuestas Particulares, tres dos cales (Real de Eclesiásticos, Personal de Legos e Personal de Eclesiásticos) usamos no presente traballo en combinación coas Respuestas Generales ${ }^{3}$.

\subsection{O catastro como fonte directa nas cien- cias sociais}

O catastro de Ensenada é unha das fontes documentais máis importantes para a reconstrución histórica do século XVIII español e galego. Tanto, que sería improdutivo tratar de detallar aquí todas as obras que ao longo dos tempos botaron man do mesmo para descifrar importantes datos históricos, xeográficos, demográficos etc. do devandito século que, doutra maneira, serían difíciles de rastrexar. Abonden algúns sucintos exemplos nos eidos da historia (Fernández Díaz 1993), a economía (Saavedra 2008: 245-275), a historia social (Marcos Martín 2000), a historia local (Blanco e García 2007) ou a xeografía (Río Barja 1990). Non obstante, no eido da lingüística o aproveitamento ten sido ata o de agora máis restrinxido e circunscrito, practicamente, ás pescudas onomásticas. Así, Carrasco e Navaza (2014) abordan a toponimia do Val de Fragoso (Vigo) axudándose, entre outras fontes, do catastro de Ensenada; na mesma liña, o proxecto do Dicionario dos apelidos galegos, impulsado polo Instituto da Lingua Galega, conta coa fonte para testemuñar documentalmente certas formas antroponímicas. Incluso na lingüística castelá, idioma no que foi redactado, o catastro non parece ter moito percorrido, alén da onomástica ${ }^{4}$, como fonte para os estudos da lingüística histórica. Neste sentido, é destacable unha obra coma a de García Godoy (2012), que, partindo da idea de que a historia do castelán moderno non foi suficientemente investigado, agrupa un

Para información adicional sobre o catastro, as súas características, contexto socio-político, autoría e finalidade, véxase, entre outros, Camarero Bullón 2002: 61-68, Gómez Urdáñez 1996 ou PARES. Para as súas características no país galego, Saavedra 2011: 685-704.

4 Repárese, como exemplos ilustrativos disto, dúas contribucións: unha que recalca xa no propio título a especificidade da fonte para a onomástica (Gordón Peral 2001: 437-454) e outra que só traballa a toponimia dentro do que anuncia como "investigación lingüística” (Molina Díaz 2006: 1153-1164). 
compendio de traballos sobre as características da lingua no século XVIII nos que, malia ser o catastro unha obra do mesmo século, non se toma como fonte investigadora dentro dos novidosos corpus que empregan para as ditas pescudas. Paralelamente, ningún dos corpus de referencia do castelán para o estudo histórico da lingua (CORDE e CE) inclúe documentos do catastro entre a súa nómina de textos.

Sexa como for, e sen esquecer a súa idoneidade para os estudos lingüísticos diacrónicos do castelán en consonancia con Tabernero, Pichel e Enrique-Arias (2020: 177-217), pretendemos demostrar a súa validez tamén no caso do galego e, en consecuencia, o beneficio de corrixir a situación actual descrita na que a fonte, alén do aproveitamento doutras disciplinas humanísticas, vén arrastrando unha escasa funcionalidade dentro da lingüística, limitándose as máis das veces á área da onomástica.

\subsection{Corpus seleccionado}

Para levar a cabo o traballo optouse por conformar un corpus variado no que ten a ver coa tipoloxía documental; dentro do propio catastro de Ensenada, como foi sinalado, foron creados varios documentos que cumprían diferentes finalidades cando foron elaborados. Así, polo xeral os interrogatorios requirían de máis descricións pormenorizadas mentres os demais documentos, ao constituíren listaxes de bens, xeralmente podían carecer de maior complexidade oracional. Tendo en conta que a lingüística histórica abrangue e investiga todos os niveis gramaticais, parece razoable que o corpus sexa variado, xa que diferentes tipos de textos poden achegar diferentes características que serán de maior ou menor interese para cada área gramatical: como poderá constatarse, os 4 tipos diferentes de textos que incluímos conteñen trazos relevantes para o estudo.

Así pois, seleccionamos o Real de Esclesiásticos (en diante, REcl), o Personal de Legos (PLeg) e o Personal de Esclesiásticos (PEcl), amais dos interrogatorios. Todos os documentos pertencen á actual comarca galega de Barcala, situada no occidente galego; por cuestións de espazo, a mostra inclúe 3 interrogatorios: Interrogatorio de San Cristóval de Corneira y otras en él comprehendidas (en diante, IC), Interrogatorio de las feligresias de Santa Eulalia de Logrosa y San Julián de Negreira (IL) e o Interrogatorio del coto feligresía de San Pedro de Bugallido (IB). Entre os tres, achegan información histórica sobre 11 das 32 freguesías coas que conta a comarca actualmente e atópanse en formato dixital descargable no portal PARES, ademais dos orixinais no Archivo General de Simancas e da versión microfilmada do Arquivo Histórico Universitario da Universidade de Santiago de Compostela. Por outro lado, os únicos documentos alén dos interrogatorios que se conservaron foron os tres devanditos (REcl, PLeg, PEcl) e todos pertencen á freguesía de San Cristovo de Corneira; consérvanse en soporte físico no Arquivo do Reino de Galicia da Coruña ${ }^{5}$.

\section{Galeguismos nos textos e a súa tipoloxía}

Por norma, e por motivos históricos e sociolingüísticos que teñen que ver co prestixio, a consideración social e o uso oficial da lingua a nivel estatal a mediados do século XVIII, a vontade (única posible) dos escribáns implicados na redacción dos documentos catastrais, documentos moi formais naquel momento, é a de escribir nun castelán correcto ${ }^{6}$. Así, se na onomástica as páxinas do catastro presentan influencias do castelán en voces galegas por tentar escribir de xeito esmerado na primeira das linguas (cf. Vidal Fonseca 2016: 99-117), no resto de palabras (non onomásticas) dos documentos atopamos influencias galegas en voces castelás; isto é, interferencias da lingua do medio que rodea a elaboración dos textos (galego) na lingua na que estes eran elaborados (castelán). Así pois, do mesmo xeito que as intervencións castelanistas na onomástica permiten ponderar o contexto sociolingüístico nesa época e nese lugar, as interferencias galeguizantes na redacción do texto permiten unha pequena aproximación tanto ao ambiente lingüístico en que se fixeron e escribiron os documentos como á formación dos escribáns e as circunstancias en que tiveron que facer o seu traballo. En xeral, preséntanos información sobre o galego do século XVIII, en particular do falado no Val de Barcala.

5 O traballo de identificación das formas galegas sustentouse nun traballo de edición previa da fonte; a exposición da necesidade dese labor exhaustivo previo e os criterios empregados atópanse en Vidal Fonseca 2020.

6 Para máis información sobre motivos e cuestións históricas implicadas, vid. Mariño Paz 1998: 195-235. 
Clasificamos ordenadamente os galeguismos que atopamos segundo sexan fonéticos, morfolóxicos, léxicos ou semánticos. Para facilitar o labor contrastivo por parte do lector, indicamos dentro de cada entrada o número de veces que aparecen nos 6 documentos entre parénteses, así como os documentos (abreviaturas) e folios correspondentes onde se poden atopar as voces.

\subsection{Galeguismos fonéticos}

\subsubsection{Alteración do vocalismo átono}

$\S$ coltura (1): IL: 472v.

Esta variante de cultura, afectada por un fenómeno de disimilación vocálica con abertura da vogal pretónica, ten doada xustificación na deriva variacional do galego común e popular (Ferreiro 1999: 198). Se a este dato sumamos a súa nula presenza na produción escrita en castelán (CORDE) e nos seus dicionarios e, pola contra, o rexistro de 4 ocorrencias desta variante da palabra en documentos galegos do século XX (TILG) cobra forza a consideración desta ocorrencia como un caso de galeguismo fonético.

$\S$ elijidos (1): IB: $118 \mathrm{v}$.

A variante elijir do verbo elegir, con asimilación regresiva ou anticipatoria, aparece, segundo NTLLE, só 1 vez nos dicionarios do castelán (Diccionario de Gaspar y Roig, 1853), que a cataloga como voz antiga: "v. a. ant.: ELEJIR". Tendo en conta a forma galega elixir, con $<\mathrm{i}>$ pretónico non inicial, e mais o contexto galegófono que rodeou o labor dos escribáns e a propia elaboración do documento, sería imprudente descartar a posibilidade de se tratar dun galeguismo fonético.

$\S$ maravidís (1): REcl: $8 \mathrm{v}$.

Alén de que a forma maravidí, afectada por unha asimilación tan corrente no galego desde as súas orixes (vid. Ferreiro 1999: 195-198), non ten cabida en dicionarios españois e galegos pretéritos (NTLLE, DdD), é significativo que só haxa un caso na documentación castelá (CORDE) por 8 casos na galega (TILG), que como é sabido non é tan abondosa. Tendo en conta o contexto, logo, é moi posible que se trate dun galeguismo fonético.

§ menutención (1): IL: 474r.

A palabra alterna unha vez, no mesmo documento, con manutención (IL: 472v), polo que se trataría, como mínimo, dunha manifestación da tendencia galega a alterar as vogais situadas en contexto átono, moi común no galego (Ferreiro 1999: 48-56). Coa cautela necesaria podemos presumir o seu carácter de galeguismo fonético ao aparecer nun texto sen dúbida influído pola lingua oral galega e por carecermos de testemuños da palabra en NTLLE e CORDE.

$\S \operatorname{metad}(4)$ IC: 501v, 503r; IL: 473v; IB: 129v.

A forma alterna en todos os documentos nos que sae con mitad: en IC, 23 veces de mitad por 2 de metad; 3 por 1 en IL; e 6 por 1 en IB. Coma no caso de elijidos, tomamos en conta a influencia da forma galega metade e o contexto galegófono de elaboración do catastro para insinuar que se trata dun galeguismo fonético, como parece confirmar o feito de que os escribáns coñezan mitad e a usen maioritariamente. A forma metad aparece 18 veces, segundo NTLLE, nos dicionarios de castelán (1591-1992) se ben figura como voz antiga desde 1803, poucas décadas despois da elaboración dos nosos documentos.

§ párracco / párracho (2): IB: 124v, 126r.

Tanto CORDE como NTLLE deixan clara a inexistencia da palabra en textos ou dicionarios do castelán. Tendo en conta o contexto galegofalante no que se elaboraron os documentos, é posible a súa explicación como fenómeno asimilatorio (neste caso inducido polo $<a>$ tónico inicial) tan común no galego desde a Idade Media (Ferreiro 1999: 195).

\subsubsection{Seseo}

Testemuñamos casos de seseo directo nos seguintes casos:

$\S$ cavesas (1): IL: 475r.

A mesma voz aparece coa grafía $<\mathrm{Z}>$ (no canto de $<_{\mathrm{S}}>$ ) outras 3 veces no mesmo documento (IL: 470r, 479v, 483v), así como 2 veces máis en PLeg, 3 en IB e 1 vez en IC na palabra encavezado. Mariño Paz (2017), a través de diversos documentos e testemuños da Idade Moderna (particularmente o padre Sobreira), afirma que lugares tan afastados hoxe das áreas de seseo explosivo como Ribadavia tiñan seseo a mediados do século XVIII. Para nós, este dato non supón máis que unha confirmación do que ao longo dos documentos do catastro podemos comprobar: abundantes testemuños de seseo na onomástica e, como ilustra este caso, tamén 
alén dela no léxico común. Trátase, daquela, dun galeguismo fonético; hipótese reforzada, ao noso xuízo, polo feito de que haxa vacilación e empregue a grafía $<\mathrm{z}>$ nos outros 3 casos.

\section{$\S$ consepción (1): IC: 496v.}

Nin NTLLE nin CORDE testemuñan a súa presenza no castelán. Trataríase, pois, dunha forma afectada por seseo e polo tanto un galeguismo fonético ( $v i d$. cavesas e paíz).

\section{$\S$ persive (1): IL: 476v.}

Forma seseante que flutúa no mesmo texto con percive: $475 \mathrm{r}, 478 \mathrm{v}, 481 \mathrm{v}, 482 \mathrm{r}$; ademais, a forma sen seseo aparece outras 5 veces en IC, 13 en REcl e 6 en IB. O feito de escribir a palabra con seseo só unha vez fronte ás 4 en que o fai sen o mesmo demostra que en moitos casos o escribán coñece a forma escrita correcta dunha palabra pero que a rapidez de transcrición e, sen dúbida, un contexto auditivo galegofalante e seseante, inflúen na ocorrencia de formas coma esta, nas que operará a mesma fenomenoloxía explicada para cavesas e paíz. Considerámola, pois, galeguismo fonético.

Por outra parte, noutros casos o testemuño seseante non nos chega de xeito directo, senón a través de hipercorreccións. Velaquí os casos:

§ paíz (5): IC: 500v; IL: 471v, 473r, 478v, 480r.

A forma flutúa con país nos mesmos documentos (IC: 483v, 501v; IL: 472v). Como explica Mariño Paz (2017: 474-483), o seseo é un trazo fonético posmedieval e típico no galego, e con máis extensión aínda en contexto posnuclear e final de palabra, onde "non se produciu a posterior extensión analóxica de $/ \theta$ / á posnuclear final de palabra (lus)" desde "a interdentalización de /s/ na posición silábica prenuclear (luces)" (Ibid.: 476). A inequívoca situación da comarca da Barcala como área seseante tanto actualmente como no século XVIII (Ibid.: 482; Álvarez e Xove 2004: 501-525) e o afán sempre intenso dos escribáns de seguir un modelo de lingua culto e formal condúcennos a dúas conclusións. Primeiro, que non é probable que en paíz haxa un testemuño de ceceo. E segundo, que debe de tratarse máis ben dunha hipercorreción por, equivocadamente, interpretar a pronuncia de país como afectada por seseo, tan común na zona xa nestas épocas. A aparición do seseo non foi un fenómeno exclusivo de Galiza no contexto ibérico nin moito menos; para mediados do século XVIII xa se distinguirían áreas de non seseo e seseo en castelán (vid.
Lapesa 1981: 373-375; Cano Aguilar 2004: 842-848) e, coma no galego, este fenómeno, contrariamente ao prestixio do que gozaba a pronuncia / $/ \theta$ / no castelán (Mariño Paz 2017: 478-479) estaría estigmatizado e asociado á incorrección (González Cruz 1995), motivo polo cal o escribán trataría de corrixilo sempre que o detectase. Polo tanto, consideramos paíz un galeguismo fonético indirecto, porque aínda que o seseo non sexa exclusivo do galego as páxinas do catastro nas terras da Barcala están elaboradas nun contexto no que a lingua que está a influír sobre o castelán que usa o escribán é o galego seseante.

\section{$\S$ peñazcosos (1): REcl: 39v.}

Nin no CORDE nin nos diferentes dicionarios de castelán (NTLLE) atopamos por ningures esta hipercorrección por seseo, nin como adxectivo nin como substantivo (*peñazco). Polo tanto, adxuntámolo ao grupo de galeguismos fonéticos e remitimos a cavesas e paíz para información adicional.

§ poseción (1): IL: 481r.

Se ben é posible enmarcala dentro dunha hipercorrección por seseo e, polo tanto, como galeguismo fonético indirecto, a palabra aparece ata en 29 ocasións en 11 documentos do castelán (CORDE), e case todos na Idade Moderna. É posible, pois, que se trate dunha hipercorreción cultista (confusión co sufixo -ción) común na época tamén nos documentos casteláns, aínda que non podemos perder de vista, igual que en autúa (vid. infra), o contexto galegofalante (e seseante) no que redacta o escribán e que puido influír nesa grafía.

§ subcidio (1): REcl: 8v.

A frase enteira, que permite unha interpretación inequívoca como subsidio, é a seguinte: "Paga por razón de subcidio y escusado ciento y cinquenta y un reales vellón y diez y seis maravidís". Só hai unha ocorrencia da forma en CORDE e ningunha en NTLLE. Trátase, pois, dunha hipercorrección de seseo que relacionamos como galeguismo fonético indirecto (vid. cavesas e paíz).

$\S$ utencilios (1): IL: 479v.

A forma recta utensilios aparece só 2 veces e noutro documento (IC). Non hai exemplos documentais de utencilios en castelán (CORDE e NTLLE) e, baseándonos no xa exposto para cavesas e paíz, determinamos esta hipercorreción de seseo como galeguismo fonético indirecto. 


\subsubsection{Despalatalización}

§ subenca (1): REcl: $22 \mathrm{v}$.

Se ben juvenca aparece nos dicionarios de castelán como voz antiga e pouco usada (NTLLE) co significado de "novilla", en subenca hai un claro testemuño de galeguismo fonético ("xuvenca"): unha despalatalización de fricativa palatal, dialectalmente esperable, segundo Fernández Rei (1990: 56), nesta comarca seseante. Hai que poñer este fenómeno en relación, tanto pola época como pola zona, con $U n$ testamento do galo de 1786, carta editada por Álvarez e Xove de Manuel Tuñas a seu curmán Pedro Tuñas. A edición e estudo conclúe que a carta se sitúa "nas terras de Barcala" (2004: $520)$ e tamén sinala que o autor recorre sistematicamente á grafía $<\mathrm{s}>$ para representar o son fricativo palatal xordo, un fenómeno explicable tendo en conta que "o escribente procede dunha área de forte despalatalización de $/ \mathrm{S} /$, un fenómeno (...) de orixe non moi recente" (Ibid.: 508). De feito, segue sendo moi frecuente na comarca da Barcala, a día de hoxe, escoitar esta pronuncia despalatalizada en xente de todas as idades. Se as terras da Barcala eran unha área de forte despalatalización de / $/$ tamén no século XVIII, vemos con toda seguridade na forma subenca unha vacilación gráfica do escribán inducida por ese fenómeno dialectal e, polo tanto, ha de considerarse un galeguismo fonético. Se ademais, de acordo co NTLLE, juvenca era unha voz antiga e pouco usada no castelán do XVIII, temos argumentos suficientes para afirmarmos que neste interrogatorio do catastro se pode considerar tamén un galeguismo léxico.

\subsubsection{Outros fenómenos consonánticos}

Ademais dos mencionados, acontecen por veces outros fenómenos consonánticos; caso, por exemplo, das oclusivas na coda silábica:

§ autúa (*autuar) (1): IL: 481r.
O paso do grupo culto latino $a c$ - $(/ \mathrm{k} /$ en posición silábica posnuclear) ao galego medieval e moderno como au- (vogalización en /aw/) está máis que documentado como patrimonial galego (Mariño Paz 2017: 519-521). Non obstante, neste caso, o feito de documentarse a voz autuar ata 5 veces nos dicionarios de castelán (NTLLE) desde 1846, e en todos os casos declarándoa voz antiga, impiden afirmar categoricamente que se trate dun galeguismo fonético. Ora ben, o feito de que estes interrogatorios do catastro se escribisen en contexto netamente galegofalante fai presumir que con toda a probabilidade é ese substrato galegófono o que funcionou neste caso como indutor do uso de autuar. Non obstante, pola súa rendibilidade nos textos destacan as hipercorreccións inducidas pola tendencia a debilitar as consoantes oclusivas na coda silábica:

§ expecie (2): IC: 483r; IB: 128 r.

A palabra aparece 18 veces máis no mesmo documento como especie; do latín SPECIES (Corominas e Pascual 1983) e tamén con só 4 ocorrencias no CORDE, consideramos posible a súa caracterización como galeguismo gráfico seguindo o razoamento que expoñemos na palabra exte (infra).

$\S$ exte (1): IL: 480v.

A forma este aparece 17 veces máis no mesmo documento. Ramón Mariño sinala que, na Idade Moderna,

nas voces en que $/ \mathrm{ks} /$ se presentaba como grupo homosilábico seguido de consoante explosiva (...) chama a atención a frecuencia con que se deron usos hipercultos de ex- en lugar de es-, por veces carentes de todo fundamento etimolóxico: exgrime 'esgrime', exmagar 'esmagar"” etc. (Mariño Paz 2017: 522-523)

É o mesmo caso que temos diante; procedente do latín ISTE, só pode considerarse un hipercultismo ${ }^{7}$. Polo tanto, a súa formulación

\footnotetext{
Ao longo dos 6 documentos proliferan casos de grafías hipercultas: axcender(án), en IC, cunha grafía hipercorrecta $<\mathrm{ax}>$, en lugar de $<$ as $>$, motivada, con certeza, polo mesmo motivo: a tendencia a debilitar as consoantes oclusivas na coda silábica, característica do galego popular desde a Idade Media. Sería o mesmo caso de adicciones, extablecimiento, exsivieron, exsactitud, exsixe, exsistencia, exsigen, exsiste, exsisten ou a do apelido Octero. Dada a súa abundancia e variedade non sinalamos todos os folios e documentos onde aparecen, mais incluímolas como hipercorreccións influídas por trazos fonéticos do galego en consonancia con exte e expecie. No caso contrario, por exemplo, atopamos ata en 11 ocasións en IC a palabra castelá *lutuosa (luctuosa). Neste caso, en vez de darse unha grafía hiperculta omítese a representación da oclusiva $/ \mathrm{k} /$ na coda silábica (luctuosa), sen dúbida por influencia do tratamento que se lle daba a estas consoantes no galego da época. Esta omisión é moi rara no castelán da época, como determina o CORDE.
} 
como galeguismo gráfico é plausible, visto que ademais o percorrido gráfico en castelán desta palabra é moi escaso (só 4 ocorrencias no CORDE).

\section{§ obpinión (1): IC: 477r.}

A xulgar polo étimo da palabra, do latín OPINIONEM (Corominas e Pascual 1981), trataríase dun latinismo hiperculto moi infrecuente, por outra parte, en galego (Mariño Paz 2017: 518), así como, segundo parece, en castelán (ningún rexistro en NTLLE e CORDE). Sen conexión, pois, co galego oral e sen apenas comuñón cos costumes gráficos galegos modernos, pode ser unha hipercorrección probablemente inducida pola presumible tendencia do escribán, seguramente galego, a debilitar ou eliminar as consoantes oclusivas dos cultismos na coda silábica.

$\S$ sesta (4): IB: 120r, 125r, 131v, 133r.

Este ordinal só aparece en IB (os outros só usan a forma sexta/o), mentres o escribán de IB só usa a palabra con esa grafía e nunca con $<\mathrm{x}>$. En palabras de Mariño Paz (2017: 412), no caso do grupo homosilábico [ks] interior de palabra en latinismos grafados con $<x>$ nese contexto, como é o caso, "non faltaron as solucións cultas representadas con $<\mathrm{x}>$, mais (...) no galego medieval, coma no portugués, no castelán e noutros romances (...) houbo unha forte tendencia á acomodación popularizante" coma en SEXTU > sesto. De feito, esta forma aparece 7 veces nos dicionarios de castelán desde o século XVII ata o XX remitindo a sexto (NTLLE). Pero ademais, no galego medio Mariño Paz detecta "preferencia polas variantes conservadoras" (2017: 522), como se pode ver nos outros cinco documentos que manexamos, en que se dá un tratamento contrario ao que se observa en IB. Así, esta forma pode ser considerada un galeguismo fonético, tendo en conta o contexto onde foi elaborado o documento, mais non necesariamente ha de selo, xa que tamén se trata dun fenómeno presente en castelán.

Por último, existe outro caso de fenómeno consonántico que ten que ver co tratamento das fricativas no ataque silábico:

§ satishaze (1): IC: 496v.

A palabra contrasta co participio satisfecho(s), que aparece 9 veces no mesmo documento. O verbo hipotético satishazer ou satishacer non aparece nunca nos dicionarios de castelán (NTLLE) mais si unhas dez veces en CORDE, todas no século XVI. Polo tanto, aínda que poida tratarse dun galeguismo fonético indirecto por hipercorrección baseada na equivalencia 'gal. F- : cast. H-' (facer : hacer, faba : haba etc.), non é segura esta afirmación, xa que tamén podería tratarse dunha variante rara do castelán con limitada pero certa tradición documental anterior ao século XVIII e xa en desuso nese século.

\subsection{Galeguismos morfolóxicos}

$\S$ bueis (4): IB: 124v, 129r, 130v.

A forma bueyes sae 123 veces en documentos en castelán polas 49 de bueis (CORDE), e case todos os casos de bueis son medievais, sendo o caso máis tardío en 1627 (CORDE). Este dato é interesante, xa que se o sumamos ao feito de constituír bois a forma galega e ao de elaborarse o catastro nun contexto galegófono é moi presumible pensar que bueis sexa unha tradución defectuosa de bois e polo tanto un galeguismo morfolóxico. Repárese, a este respecto, na formación do plural en agudas rematadas en vogal en castelán (zulú : zulúes, sí : síes) e en galego (zulú : zulús, si : sis).

$\S$ carretar (1): IB: $135 \mathrm{v}$.

Só aparece 3 veces nos diversos dicionarios de castelán, como rexistra NTLLE: 1786, 1853 e 1895, ningún deles era o elaborado pola Academia Española e todos a sinalan como voz antiga e remiten a carretear (amplamente tratada, esta si, nos traballos lexicográficos) ou acarrear; o CORDE, pola súa banda, non rexistra a voz. Pharies (2002: 184-185) explica que en castelán o sufixo -ar polo xeral é máis antigo que -ear e que, agás casos de especialización semántica, nos casos de convivencia de significado - ear acaba normalmente triunfando sobre -ar. $\mathrm{O}$ feito de que se rexistre como voz antiga en 1786, pouco despois da elaboración do catastro, e de que exista unha palabra galega idéntica leva a pensar que esta forma verbal é tamén un galeguismo, neste caso, morfolóxico, no que ten a ver coa forma de facer a derivación a partir de carro: carr-et-ar fronte a carr-et-ear.

$\S$ da (contracción) (1): IL: 477r.

O contexto oracional desta contracción é o seguinte: "está sito en el lugar da Barca". Se contrastamos a solución que dá neste caso o escribán ao contacto da preposición de mais un artigo incluído nun topónimo co tratamento castelanizante que recibe este artigo na maioría 
dos topónimos ${ }^{8}$, só podemos considerar o resultado final un galeguismo morfolóxico, toda vez que a forma é imposible no castelán (de + la).

\subsection{Galeguismos sintácticos}

\subsubsection{Perífrase $i r+$ infinitivo}

\section{$\S$ ba fenecer (1): IC: 479r.}

A frase contextualizada é a seguinte: “cuyos linderos: principian por levante en donde llaman Couto Carballo, de allí ba a la fuente Pouliñosa, (...), de allí al sitio de Froxende, y ba fenecer al marco do Couto Carballo, donde principió". Contrasta no mesmo documento con IC: $479 \mathrm{v}$, no que aparece "ba a fenecer". Segundo Fernández Martín (2018: 99-101) a perífrase ir a + infinitivo existe en castelán polo menos desde o século XVII, e testemuña varios exemplos en escritores da época como Quevedo ou Lope de Vega. Yllera (1980: 174-175) vai máis lonxe e, ademais de situalas na Idade Media, determina que foi a mediados do século XV cando o uso desa perífrase se vai consolidando coa preposición $a$, logo dun período medieval de alternancia (con e sen preposición). Por último, Flores Dávila (2014: 1307) amósase rotundo á hora de situar o triunfo en castelán da preposición $a$ nesta construción perifrástica:

\begin{abstract}
Por lo que respecta al castellano, la inserción de $a$ fue un cambio gradual pero relativamente rápido (...). En la segunda mitad del siglo XIII la presencia de $a$ en el sintagma ir + infinitivo tenía apenas $14 \%$; en los siguientes 140 años se triplica ese porcentaje en avances cuantitativos muy notorios y continuados; para la segunda mitad del siglo XV, la inserción de $a$ alcanza casi $80 \%$ y para el siglo XVI no hay documentaciones sin esta preposición en los constructos con $i r+$ infinitivo.
\end{abstract}

Así pois, coa debida cautela, podemos presumir a súa caracterización como galeguismo tendo en conta o contexto galegófono que acompañou a realización dos documentos.

\subsubsection{Verbo transitivo + CD humano}

$\S$ tiene en su compañía [nome propio humano] (11): PLeg: 2r, 2v, 3r, 5r, 7v, 8r, 8v, $9 \mathrm{r}, 9 \mathrm{v}, 10 \mathrm{r}$.

Estas construcións chaman a atención pola ausencia da preposición $a$, típica do castelán marcando o complemento directo do verbo transitivo. Como indica Laca (2006: 423-475), a aparición en castelán desta marca ante complemento directo cando este é un pronome ou nome humano é xa medieval e sistemática incluso no século XIII (96\% dos casos analizados pola autora), sen variación nos textos dos séculos seguintes ata os nosos días. De feito, a extensión histórica do uso preposicional a outras clases de complemento directo dáse desde os casos de 'CD pronome/nome humano' (e outras categorías achegadas) cara a outras menos humanas, animadas ou definidas (2006: 436437,448 ), o que quere dicir que, de sempre, o castelán presenta preposición diante de obxecto directo consistente nun nome propio humano. Laca (2006: 447) só atopa unha pequena baixada na sistematicidade de uso nos textos que analizou no século XVIII, pero explícaa perfectamente por cuestións de contexto (nome propio con uso metonímico ou funcionando como común, complemento directo que segue a un indirecto etc.). No caso do galego, a estrutura desprovista da preposición nestes casos é máis esperable: Mariño Paz (2003: 259-261) cataloga a súa aparición como infrecuente na Idade Media e, malia ir estendendo os contextos de uso durante a Idade Moderna, o seu uso diante de nomes propios en $\mathrm{CD}$ nin sequera se chegou a universalizar completamente na actualidade, onde é habitual notar a súa ausencia na fala popular, e "non chega a ser completamente obrigatorio" na norma (Cidrás Escáneo 2006: 147). De feito, este mesmo autor indica que "na lingua oral de hoxe, os exemplos máis factibles" de non aparición da preposición "corresponden a estruturas cun moi baixo perfil de transitividade: verbos estativos (...), basicamente, ter (o verbo transitivo máis atípico)" (Ibid.: 158). Precisamente, o verbo ter é o que rexe todos os casos do fenómeno nos nosos textos.

No caso de como se produciu no castelán a extensión da preposición desde o medievo sinalada por Laca, Girón Alconchel (2004: 875876) indica que para finais do século XVII o CD xa aparece "raramente" sen a preposición (o cal concorda coa pescuda da autora), se ben non co nivel de fixación que ten o castelán actual, mentres que xa no XIX Bello (2002) sinalaba a obrigatoriedade da súa presenza diante de nomes propios. Polo tanto, se xuntamos a posibilidade medieval, posmedieval e actual dunha frase do tipo [Suxeito] ten na súa compaña Xosé no galego coa baixa posibilidade 
dunha frase similar, tamén sen concorrencia da preposición $a$, no castelán de mediados do XVIII e a isto engadimos o contexto galegófono que está omnipresente na elaboración dos nosos documentos, chegamos á conclusión de que, máis que probablemente, a estrutura Tiene en su compañía [nome propio humano] aparecida repetidamente en PLeg constitúe un galeguismo sintáctico.

\subsection{Galeguismos léxicos}

$\S$ agra (1): REcl: 40r.

Á parte das innúmeras veces que esta palabra aparece nos seis documentos como voz onomástica (apelido ou topónimo), aparece unha vez no contexto "Que las piezas de tierra que suenan de un mismo nombre están comprehendidas con el de la vega o agra donde se allan situadas". O dito contexto é moi aclarador, xa que o mesmo achega a definición aproximada de agra (é dicir, "o vega"). Na nosa opinión, o escribán tenta escribir nun castelán o máis esmerado posible usando a palabra vega pero, como é consciente de que o termo non dá conta da complexidade da agra galega ${ }^{9}$, ten que matizar a primeira usando esta última. Tamén é posible que o escribán temese que os seus principais lectores no aparato do Estado non entendesen o significado de agra, cunha clara dimensión xeográfica e agraria galega, e por iso achega unha palabra como vega para transmitir unha idea de a que se refería. Sexa como for, agra non aparece por ningures nos dicionarios de castelán (NTLLE, RAE) co significado galego de "grande extensión de terra de cultivo dividida en leiras ou agros que pertencen a distintos donos" (RAG) e, polo tanto, a súa aparición no noso texto constitúe un galeguismo léxico.

$\S$ aira (2): REcl: 3r, 9v.

Sen necesidade de entrar nunha investigación etnográfica e cultural sobre o valor semántico completo que tería a palabra aira dentro e fóra de Galiza (RAG, a diferenza da definición da palabra equivalente en castelán da RAE, indica "terreo próximo á casa"), a palabra constitúe un galeguismo léxico pleno, posto que non aparece en ningún dicionario de castelán incluído o actual (NTLLE, RAE) e nas ocorrencias de CORDE nunca ten ese significado (en case todos os casos sae como forma conxugada do verbo airar). $\mathrm{O}$ tradutor Gaio indica o equivalente castelán, era, que na súa segunda entrada (RAE) é a palabra que carrexa o significado similar, cos anteditos matices, ao que ofrece o dicionario RAG para eira (posto que aira, como sinónimo, remite á forma eira). $\mathrm{O}$ único misterio que nos quedaría por explicar, e que seguramente terá que ver coa formación ou orixe do escribán, é a presenza do galeguismo na súa variante diatópica oriental (provincia de Lugo e case toda a de Ourense), aira, cando pola situación da comarca da Barcala cabería esperar eira, xa que como explica Mariño Paz (2017: 144-145, 295) a distribución diatópica deste par, igual ao doutros con secuencias ditongais idénticas, xa estaría clara desde a Idade Media (cf. ALGa, vol. 3, mapa 90).

§ canle (13): IL: 477r, 477v; IB: 126r, 126v, $127 \mathrm{r}, 127 \mathrm{v}, 128 \mathrm{r}$.

Non hai constancia desta palabra en ningún dicionario de castelán (NTLLE), como tampouco a nivel documental no CORDE. Nos textos preséntase caracterizando como núcleo dunha frase preposicional a palabra muíño ("de canle") para diferencialo doutro tipo de muíños. Como indica o tradutor Gaio, o seu equivalente en castelán é canal, unha solución menos evoluída a partir do seu étimo CANALE (Ferreiro 1999: 132); como indica este autor, a forma canle (con grupo heterosilábico - $n l$-) fronte á variante cal dáse máis xeralmente nas zonas occidentais, como é a nosa ${ }^{10}$; iso, e se cadra o descoñecemento da equivalencia coa forma castelá canal (ou cando menos no contexto semántico da tipoloxía de muíños) poderían explicar a aparición deste galeguismo léxico ${ }^{11}$.

§ carreto (3): IB: 135v, 136r.

O contexto da expresión deixa clara a súa categorización como substantivo, valor que non ten nin tivo en castelán, a xulgar polos datos de NTLLE e dicionario da RAE; incluso no CORDE: só se testemuñan 3 veces co significado

\footnotetext{
9 As súas implicacións na realidade social e agraria como espazo de cultivo fechado por valos, preto das aldeas e dividido en agros, mestura de propiedade privada e cultivo comunal (Cardesín 1992), serían certamente descoñecidas no centro da coroa.

10 Así o confirma o ALGa, volume III (mapa 215), no que se pode trazar unha liña recta imaxinaria aproximada desde a cidade da Coruña ata os puntos máis setentrionais da divisoria entre as provincias de Pontevedra e Ourense a cuxa marxe esquerda, exceptuando puntos do Salnés, se dá a forma canle en contraste coa marxe dereita.

11 Repárese no topónimo deturpado Canal de Puente Corneira, no que intervén un escribán diferente (REcl: 4r).
} 
e valor do texto, das cales 2 son en obras da galega Emilia Pardo Bazán. Pola contra, DdD testemuña 29 veces a expresión, definíndoa sempre como acción e/ou efecto de carretar e, no caso de dicionarios galego-castelán, sempre como sinónimo de acarrear; tamén o dicionario da RAG, contrariamente ao RAE, inclúe a voz como "acción e efecto de carretar". Quedan poucas dúbidas, entón, de que se trata dun galeguismo léxico.

$\S$ conca (4): IC: 482v; IB: 120v.

Castaño Álvarez (2015) explica que, á hora de medir produtos de consumo humano como sementes, pequenos froitos etc., utilizábanse envases ou recipientes que finalmente daban nome á unidade de medida e inclúe a conca nese grupo. Se contrastamos eses datos coa procendencia etimolóxica de cuenca en Corominas e Pascual (1996) advertimos o esforzo dos autores en detallar a equivalencia en "Gallego-portugués[:] conca", aclarando que "en gallego tiene hoy cunca mayor extensión, así en el sentido de 'escudilla' como en el de 'taza" (1996: 271), se ben tanto TILG (107 casos), como DdD, como o dicionario RAG dan conta da palabra conca e este último non só a cataloga como sinónimo en todas as acepcións de cunca, senón que a $6^{\mathrm{a}}$ acepción desta última é "Medida de capacidade para grans, legumes etc., que pode equivaler a 1/12 ou 1/16 dun ferrado", que sería o significado que presenta nas catro ocasións en que sae nos nosos textos, como se deduce do contexto; e, indo máis lonxe, a $5^{\mathrm{a}}$ acepción é "Medida de superficie equivalente a dous cuartillos". O dicionario RAE, pola contra, non contempla ningunha destas medidas como definición nin para conca nin para cuenca, e conca só aparece unha vintena de veces nos documentos casteláns (CORDE), en contraste cos 107 de TILG para o galego. Conca sae moitas veces nos dicionarios de castelán segundo NTLLE (41 entre 1611 e 1992) pero é curioso notar que o da Real Academia Española de 1780 (menos de 30 anos despois do catastro) catalógaa como voz antiga e remite a cuenca. Na busca desta última, finalmente, o dicionario tampouco a cataloga como medida. En definitiva, pois, a unión de todos estes datos revela inequivocamente que conca está en paralelo con lagueiro, estriga ou ferrado e que é un galeguismo léxico.
$\S$ estrigas (1): IB: $121 \mathrm{r}$.

Nin sequera unha obra especializada en unidades de medida coma a de Castaño Álvarez (2015) cataloga esta voz; moito menos, os diferentes dicionarios de castelán no transcurso dos últimos séculos, como demostra o NTLLE. En troques, si que aparece un total de 33 veces nos dicionarios galegos (DdD) desde 1746. De feito, Sarmiento di textualmente que "la voz estriga es pura gallega" (Sarmiento 1970: 290). Así pois, estamos diante doutro galeguismo léxico.

§ feligresía / felegresía (200): IC: 476r, 476v, $477 \mathrm{r}, 478 \mathrm{v}, 479 \mathrm{r}, 479 \mathrm{v}, 481 \mathrm{v}, 482 \mathrm{r}, 483 \mathrm{r}$, $483 \mathrm{v}, 484 \mathrm{r}, 484 \mathrm{v}, 485 \mathrm{v}, 486 \mathrm{r}, 486 \mathrm{v}, 487 \mathrm{r}$, $487 \mathrm{v}, 488 \mathrm{r}, 488 \mathrm{v}, 489 \mathrm{v}, 490 \mathrm{r}, 490 \mathrm{v}, 491 \mathrm{r}$, 492r, 494r, 494v, 495v, 496r, 496v, 497v, 498r, 499r, 499v, 500v, 501r, 501v, 503v, 504r, 504v, 505r; REcl: 1r, 1v, 41r, 96r; PLeg: 1r, 1v, 2r, 11r; PEcl: 96r, 96v, 97r, 97v, 98r; IL: 469r, 469v, 470r, 470v, 471r, 471v, 472r, $472 \mathrm{v}, 473 \mathrm{v}, 474 \mathrm{r}, 474 \mathrm{v}, 475 \mathrm{r}, 475 \mathrm{v}, 476 \mathrm{r}$, $476 \mathrm{v}, 477 \mathrm{v}, 478 \mathrm{r}, 478 \mathrm{v}, 479 \mathrm{r}, 479 \mathrm{v}, 480 \mathrm{r}$, $480 \mathrm{v}, 481 \mathrm{r}, 481 \mathrm{v}, 482 \mathrm{r}, 482 \mathrm{v}, 483 \mathrm{r}, 483 \mathrm{v}$, $484 \mathrm{r}, 484 \mathrm{v}, 485 \mathrm{v}, 487 \mathrm{v}, 488 \mathrm{r}, 488 \mathrm{v}, 489 \mathrm{r}$, 489v, 490r; IB: 118r, 118v, 119r, 119v, 126r, $126 \mathrm{v}, 127 \mathrm{r}, 127 \mathrm{v}, 128 \mathrm{r}, 135 \mathrm{r}$.

Esta voz presenta unha complexidade especial polas súas implicacións semánticas, co cal nos cómpre facer un percorrido histórico polo seu significado, galego e castelán, e polo uso da palabra na tradición escrita para dar conta da súa posible presenza nesta listaxe como galeguismo.

Feligresía, como tal, é unha palabra castelá que en galego ten como cognado freguesía (tradutor Gaio); documentada desde o século XIII en castelán (Corominas e Pascual 1996), aparece, segundo NTLLE, un total de 43 veces nos diferentes dicionarios de lingua castelá ${ }^{12}$, sendo do ano 1609 a primeira delas, polo cal non incluímos aquí a palabra, obviamente, como galeguismo fonético. Corominas e Pascual (1996) indican que a palabra procede de feligrés, e que esta, á súa vez, procede do latín vulgar hispánico FILI ECCLESIAE, 'fillo da igrexa'; segundo os autores, foi o prestixioso filólogo galicianista Vicente García de Diego quen confirmou a etimoloxía xa citada e, casualmente, inclúen na súa obra que, en relación coa palabra, o propio

12 Inclúe todos os dicionarios dos séculos XV a XVIII, os dicionarios xerais do XIX e XX e todos os dicionarios da Real Academia Española ata 1992. 
García de Diego "llamó la atención acerca del gall[ego] ant. figreje y su derivado figlesía, fiiglesía, fliguesía (hoy feligresía, 'feligresía, parroquia')" (1996: 878). A súa sinonimia con parroquia, sinalada polos investigadores etimolóxicos, é a que nos interesa para tratar de dilucidar, desde o punto de vista semántico, a súa configuración ou non como galeguismo.

O dicionario da Real Academia Galega define freguesía como "1 Territorio que está baixo a dirección espiritual do párroco" e "2 Conxunto de fregueses dese territorio", sinalando parroquia como sinónimo nos dous casos. Mentres, o dicionario da Real Academia Española dálle a feligresía os significados de " 1 . f. Conjunto de feligreses de una parroquia. 2. f. Territorio encomendado a un párroco. 3. f. Parroquia rural compuesta de diferentes barrios": son coincidentes as definicións 1 coa 2 de cada dicionario. Lembrando que os nosos documentos están en castelán, tanto a segunda como a terceira definicións dadas polo dicionario da RAE parecen ter cabida no contido expresado polos interrogatorios e os libros persoais; se botamos man do dicionario anteriormente máis próximo á época de elaboración do catastro que incluía a voz feligresía, o da RAE de 1732 (NTLLE) vemos que nel se definía feligresía como "El distrito $\mathrm{y}$ vecinos que pertenecen à una Parróchia", correspondéndose ben, pois, coas que no dicionarios RAE e RAG actuais están desglosadas (acepción 1: distrito ou territorio; acepción 2: conxunto de veciños ou fregueses). Non obstante, cómpre facer un percurso sobre a historia do país para chegar a unha mellor comprensión do termo. En palabras de Torres Luna e Lois González (2009: 22),

A organización territorial do país non se podía comprender á marxe da parroquia. A parroquia definiuse e defínese como unidade de delimitación eclesiástica, que ao longo da Idade Media e até os nosos días se consolidou como célula básica de relación social no agro, espazo delimitado ao que lle correspondían bens comunais, microcosmos da existencia labrega (cun ritmo anual de festas e eventos perfectamente pautado), ámbito da cooperación veciñal e lugar preferente de pertenza das persoas, por enriba da aldea (ou o barrio, ou a vila, etc.) e da bisbarra de orixe. Para os xeógrafos, as freguesías interprétanse sob[r]e todo como territorios, que se representan con límites precisos nos mapas de Galicia. As parroquias engloban un número moi variable de entidades singulares de poboación.

O proceso de conformación das freguesías, tal e como as describen os mencionados xeógrafos, foi longo e, segundo os autores do primeiro nacionalismo galego (Otero Pedrayo et al.), estende as súas raíces primixenias ata a época prerromana, no hábitat celta: aldeas rurais dispostas ao redor dun castro principal que se converteu, tras a colonización romana e sueva, na parroquia rural (Torres Luna e Lois González 2009: 22). Aínda así, o seu asentamento foi moi gradual e tivo na fixación do cristianismo, en especial desde o reino suevo, un dos seus alicerces fundamentais. En palabras de López Alsina (2009: 57, 60),

O sistema parroquial en Galicia ten as súas máis remotas orixes na (...) cristianización da poboación rural. No curso do século IV a organización da Igrexa no seo do Imperio tende a se acomodar ás realidades administrativas da administración provincial civil (...). A Igrexa do reino suevo prescinde da organización territorial provincial romana e adáptase ao territorio do reino.

Como queira que fose esta adaptación relixiosa á vida civil e ás características sociais da época, o certo é que, segundo os postulados do autor, o sistema parroquial tal e como o coñecemos en Galiza fica máis ou menos asentado desde o século XI, se ben o período de máximo esplendor da freguesía non se dá ata a Idade Moderna, como se deduce do estudo de Pegerto Saavedra (2009: 77-104) sobre o catastro de Ensenada, non por casualidade, a mesma obra foco do noso estudo. No espazo galego, as operacións catastrais realizáronse fundamentalmente por freguesías. Saavedra (2009: 78) explica:

A terminoloxía da época resulta xa un pouco confusa, debido a que a distribución espacial da poboación galega (e en xeral da cornixa cantábrica) se parecía pouco á que rexía en Castela. Os comisarios que se encargaron de dirixir as operacións do Catastro cansáronse de explicar á Real Junta de la Única Contribución, que supervisaba desde Madrid as operacións, que en Galicia as cousas non eran igual que no centro e sur da península, polo que non resultaba doado seguir unhas instrucións uniformes para toda a coroa de Castela. Dada a distribución da poboación en pequenas entidades espalladas, a parroquia aparecía como verdadeiro ámbito aglutinador e os párrocos como os intermediarios privilexiados entre a comunidade e as autoridades político-fiscais externas a ela.

Para o autor, o feito de que os documentos elaborados pola administración da monarquía se realizasen por freguesías (alén do catastro de Ensenada, tamén o censo de Floridablanca), 
"e non seguindo a división dos «partidos» fiscais que rexían para a repartición de alcabalas e servizos pon de manifesto a afirmación, tamén no plano administrativo, da freguesía" (Ibid.: 79). E, como dato xenérico galego da época, "é doado comprobar asemade que nos documentos notariais a freguesía figura como o marco mellor definido de pertenza das persoas que outorgan escrituras" (Id.). Todos estes datos testemuñan non só a realidade específica galega na súa organización territorial e social á altura de 1750, senón tamén o patente descoñecemento da mesma por parte da corte castelá, toda vez que a súa realidade e organización tiñan que ser ben distintas.

Queda claro, pois, que a definición e a realidade física e social das freguesías antes explicadas por Torres Luna e Lois González nin foron nin son universais no espazo peninsular ibérico; de feito, como ben precisan os autores, "as parroquias, tal e como as coñecemos, constitúen unha realidade que se estende por toda Galicia, Norte de Portugal, Asturias e determinadas comarcas de León e Cantabria" (Torres Luna e Lois González 2009: 25). Así pois, ou ben o concepto de freguesía e do seu sinónimo parroquia -definida polo dicionario da RAE de 1737 como "el distrito y território que ocupan los parrochianos, o está señalado à la Parrochia" e "jurisdicción espiritual que tiene el Cura en su distrito, ó (...) el conjunto de todos los parrochianos, como súbditos suyos" (NTLLE)- eran ambiguas ou demasiado lacónicas nos dicionarios máis achegados a 1750, ou ben dentro desa concisión non tiñan por que incluír a especifidade da freguesía galega con respecto á do centro do poder castelán. De feito, a definición actual de parroquia no dicionario da RAE é a seguinte:

Del lat. tardío parocȟ̆a, y este del gr. $\pi \alpha \rho o$ cía paroikía 'avecindamiento', infl. en su forma por el lat. parŏchus 'anfitrión', 'abastecedor'. 1. f. Iglesia en que se administran los sacramentos y se atiende espiritualmente a los fieles de una feligresía. 2. f. Conjunto de feligreses. 3. f. Territorio que está bajo la jurisdicción espiritual del cura de almas. 4. f. Clero destinado al culto y administración de sacramentos en una feligresía. En la procesión del Corpus van todas las parroquias. 5. f. Conjunto de personas que acuden asiduamente a una misma tienda, establecimiento público, etc. 6. f. Gal. En los municipios rurales, demarcación administrativa local, aunque carente de reconocimiento legal expreso. (Real Academia Española 2018; negra nosa)
Como pode observarse, as primeiras definicións son moi similares ás que xa ofrecía o dicionario de 1737 (incluída a acepción 1); non obstante, todas esas concrecións non abondan para explicar a dimensión da freguesía galega, a tal punto que a última acepción, destacada por nós en negra, ten a misión de especificar que a palabra ten un significado particular e circunscrito ao ámbito de Galiza ("Gal."), que é unha concepción da palabra diferente a todas as restantes definicións. O dicionario da RAG, pola súa parte, ofrece un conxunto de definicións moi similar coa diferenza de que, por dar conta da lingua do país, non especifica, por redundante, que a devandita acepción sexa circunscrita a Galiza.

Así pois, e polo razoado ata aquí, non se pode afirmar de ningún xeito que os escribáns que usaban a palabra feligresía nos interrogatorios e libros persoais na época o fixesen botando man dunha acepción e concepción particulares da palabra castelá para a realidade galega que, como expresa Saavedra, era entidade principal e organizadora dos documentos catastrais, a diferenza doutros territorios da coroa. Dá a impresión de que os escribáns galegos que traballaron para o catastro de Ensenada usaron a palabra feligresía coa acepción de 'demarcación administrativa local, mais carente de recoñecemento expreso, propia dos municipios rurais Galiza', por máis que esta acepción non estivese recollida no dicionario RAE da época. Isto, en si mesmo, xa representa un importante indicio de que a palabra feligresía poida constituír un galeguismo semántico nos textos. Non obstante, botamos tamén unha ollada á súa distribución frecuencial nos textos para tentar determinar máis atinadamente a cuestión.

No total dos 6 documentos manexados, $f e$ ligresía aparece, en singular ou plural, abreviada ou enteira, 200 veces; 192 desa forma e 8 veces coa variante felegresía. Pola contra, non se fala de parroquia (nin coas grafías actuais nin coas súas variantes pretéritas) en ningunha ocasión; o máis aproximado a esa mesma raíz é a palabra párroco a través das súas variantes gráficas párrocho, párracho e párracco para designar o oficio sacerdotal; non obstante, nin moito menos son sistemáticas, senón que só aparecen 4 veces (IC: $476 \mathrm{v}, 504 \mathrm{v}$; IB: $124 \mathrm{v}$, 126r) e os escribáns prefiren abrumadoramente a forma cura.

Partindo da base da sinonimia entre as dúas voces, esta sistematicidade de feligresía e a total ausencia de parroquia resultan rechamantes se as contrastamos co estudo de Varela 
Barreiro (2015: 147-175) sobre o uso de ambas palabras no ámbito galego. En palabras do autor, "parroquia [é] un evidente cultismo e máis que probable castelanismo" (Ibid.: 149), o que sen dúbida contrasta coa marxinación actual da voz freguesía a un papel secundario "na elaboración do padrón actual e, sobre todo, na súa aplicación práctica na documentación oficial autonómica galega" (Ibid.: 148), como testemuñan as súas pescudas sobre a baixísima frecuencia de uso xornalístico de freguesía con respecto a parroquia e, o que é máis grave, na elaboración dos padróns toponímicos por parte da administración autonómica. Abonde como exemplo destas descompensacións a obra da cal sacamos varios artigos de interese para o apoio científico desta voz, A Parroquia en Galicia: pasado, presente e futuro (Xunta de Galicia 2009); nela, aparece a palabra parroquia unhas 2118 veces e só 361 freguesía. A nómina redúcese aínda máis se temos en conta que, desas 361, un mínimo de 190 están nun artigo que trata sobre a unidade administrativa oficial portuguesa da freguesía, que ten ese nome (Calheiros 2009: 347-370).

Tamén contrasta esa situación actual coa orixe e distribución inicial das dúas voces no ámbito da península ibérica:

No latín eclesiástico -e quizais tamén no común- da península ibérica coexistiron durante un tempo, probablemente en todo o territorio e como voces basicamente sinónimas, a voz latina

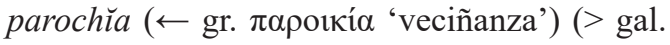
parroquia, port. paróquia, cast. parroquia, cat. parròquia) e a forma do latín vulgar filiecclesia $>$ filigresia, derivada de fili eclesiae 'fillo da igrexa' ( $\rightarrow$ gal. freguesía, port. freguesia, cast. feligresía, cat. feligresia). Con posterioridade, quizais xa desde o período do reino suevo na parte noroccidental e por mor da especificidade da súa cristianización, abriuse paso nas terras de Hispania unha diferenciación diatópica entre o territorio máis occidental (futuro romance occidental ou galego-portugués) e os territorios centro-orientais (futuros romances centro-orientais). Por ela, en territorio occidental cobraron dominancia os derivados de fili eclesíae e nos outros territorios foron os derivados de parochĭa os que acabaron por se impoñeren. Portugués, por unha banda, e leonés, castelán, aragonés e catalán, pola outra, manteñen aínda hoxe esa distribución areal en termos moi parecidos a como debeu de ser nas orixes. O galego, no entanto, parece formar parte actualmente da área de parochía, por ser a forma freguesía de escaso uso e mesmo de ton literario. (Varela Barreiro 2015: 150)
Así pois, na liña temporal galega trazada polo autor e meticulosamente indagada a través dos corpus e ferramentas lingüísticas dispoñibles, aparece a palabra freguesía, desde a Idade Media ata comezos da Idade Contemporánea, como forma case exclusiva para expresar os contidos da voz latina parochĭa. Ben é certo que nese dilatado espazo de tempo a estabilidade non é total e xa se observan síntomas de penetración da voz parroquia canto máis entrada a Idade Moderna; porén, a súa imposición definitiva non se dá ata a Idade Contemporánea. Cómpre destacar que no século XVIII o 50\% das voces aparecidas nos textos galegos xa son para parroquia e o $50 \%$ restante para freguesía, unha evolución anómala (como vimos, sen paralelo en ningunha outra lingua iberorrománica) e ata ese momento inédita (Ibid.: 162), pero que non sorprende demasiado tendo en conta que parroquia era a forma maioritaria do castelán. Se tal era a situación nos textos escritos en galego dese século, cabería agardar un resultado aínda maior nun texto escrito en castelán nese momento; de feito, o CORDE confirma esta dedución: no tramo que vai de 1725 a 1775 en textos de España só aparece 6 veces a forma feligresía e as súas variantes gráficas por 61 veces de parroquia e as súas variantes, o que amosa que esta última era a voz hexemónica do par, case única, do castelán da época, cunha distribución do $8,95 \%$ e o $91,04 \%$ respectivamente. Se incluímos todos os resultados de fóra do Estado español a distribución non mellora moito para feligresía: 42 veces $(17,43 \%)$ e 199 para parroquia $(82,57 \%)$. Así, e poñendo en común o contraste de todos estes datos, resulta moi curioso constatar como nos nosos textos se dá a circunstancia contraria: ausencia total da forma culta do castelán $p a$ rroquia e presenza absoluta da forma equivalente á maioritaria ata ese momento en galego, feligresía.

Ao noso xuízo, pois, e tras poñer enriba da mesa todos os elementos e condicionantes, a circunstancia de que a palabra feligresía, equivalente á maioritaria no galego da época, apareza no $100 \%$ dos casos dos nosos documentos cando estaba sendo substituída nos textos galegos por parroquia por contacto co castelán, e cando era practicamente marxinal nos textos españois da época, só pode explicarse como un galeguismo. Se ben non como galeguismo léxico (dando conta dunha realidade social, administrativa etc. descoñecida fóra de Galiza), cando menos como galeguismo semántico por forma coincidente coa maioritaria do 
galego: o contacto dos escribáns coas xentes galegofalantes, que usarían sempre freguesía, induciría sistematicamente a forma feligresía no canto da máis usada para o castelán, parroquia, sen nin sequera alternalas. O feito de que teñamos ata 8 casos da forma felegresía (IC: 486r, 486v, 495v; PLeg: 1v; PEcl: 96v, 97r; IL: $480 \mathrm{v}$ ), afectada por unha asimilación vocálica máis que habitual no galego popular desde os confíns do latín ata hoxe (vid. Ferreiro 1999: 195-196) apoia, ao noso modo de ver, o postulado de que os escribáns se decantaron por un calco da forma que escoitaban habitualmente e que era maioritaria en galego, un fenómeno que tamén acontecía con frecuencia nas formas onomásticas.

§ ferrado (293): IC: 482v, 483r, 483v, 484r, $484 \mathrm{v}, 485 \mathrm{r}, 485 \mathrm{v}, 586 \mathrm{r}, 486 \mathrm{v}, 488 \mathrm{v}, 489 \mathrm{r}$, $489 \mathrm{v}, 490 \mathrm{r}, 490 \mathrm{v}, 491 \mathrm{r}, 491 \mathrm{v}, 492 \mathrm{r}, 492 \mathrm{v}$, 493r, 493v, 494r, 505r, 505v; REcl: 3v, 4r, 4v, $5 \mathrm{r}, 5 \mathrm{v}, 6 \mathrm{r}, 6 \mathrm{v}, 7 \mathrm{r}, 7 \mathrm{v}, 8 \mathrm{r}, 12 \mathrm{r}, 12 \mathrm{v}, 13 \mathrm{r}, 13 \mathrm{v}, 14 \mathrm{r}$, $15 \mathrm{v}, 16 \mathrm{r}, 16 \mathrm{v}, 17 \mathrm{r}, 17 \mathrm{v}, 18 \mathrm{v}, 19 \mathrm{v}, 20 \mathrm{r}, 20 \mathrm{v}$, $21 \mathrm{r}, 21 \mathrm{v}, 23 \mathrm{r}, 23 \mathrm{v}, 24 \mathrm{r}, 24 \mathrm{v}, 25 \mathrm{r}, 25 \mathrm{v}, 26 \mathrm{v}$, $27 \mathrm{r}, 27 \mathrm{v}, 28 \mathrm{r}, 28 \mathrm{v}, 29 \mathrm{v}, 31 \mathrm{r}, 31 \mathrm{v}, 32 \mathrm{r}, 32 \mathrm{v}, 33 \mathrm{r}$, $33 \mathrm{v}, 34 \mathrm{r}, 34 \mathrm{v}, 35 \mathrm{r}, 35 \mathrm{v}, 36 \mathrm{v}, 37 \mathrm{v}, 38 \mathrm{r}, 38 \mathrm{v}$; IL: 472r, 472v, 473r, 473v, 474r, 474v, 475v, 476r, 476v; IB: 120v, 121r, 121v, 122r, 122v, $123 \mathrm{r}, 123 \mathrm{v}, 124 \mathrm{r}, 124 \mathrm{v}, 125 \mathrm{r}, 125 \mathrm{v}, 126 \mathrm{r}$, $131 \mathrm{v}, 134 \mathrm{r}$.

Malia aparecer esta unidade de medida 41 veces, desde 1609, nos dicionarios de lingua española, o certo é que o fai, case sempre, acompañada das etiquetas "Reino de Galicia", "Gal." ou similares (NTLLE). Así queda patente tamén no dicionario actual da RAE, onde salienta nas súas dúas acepcións "medida usada en Galicia” (Real Academia Española 2018). Tamén Castaño Álvarez (2015) a cataloga como medida de superficie galega, mentres o especialista Luis Pastor aclara, no mesmo senso, que esta unidade é "propia de Galicia. (...) Medida especial para granos y semillas equivalía a la $1 / 4$ parte de una fanega. Medida de superficie que equivale a 900 varas cuadradas castellanas o sea 6,29 áreas" (Luis Pastor). Hai que matizar a isto último, non obstante, que a medida do ferrado é moi diferente e oscila ao longo do territorio galego. Por exemplo, en 1753 varias das freguesías incluídas no noso traballo tiñan diferentes valores para a unidade do ferrado ${ }^{13}$. En definitiva, pois, esta voz debe ser considerada como galeguismo léxico nos nosos documentos.

§ hierval (4): IL: 471r, 472r, 473r.

A voz aparece inequivocamente como substantivo; tal e como está (ou coa grafía $<$ b $>$ no canto de $<\mathrm{v}>$ ) só sae 12 veces nos dicionarios de castelán (NTLLE) e como adxectivo, non como substantivo. Para este último agardaríase hierval (como sae precisamente en IC: 482r, 484v e en REcl: 39r) ou hierbal, pero esta parece ser unha palabra con moi pouco percorrido no castelán: só aparece nos dicionarios desde o século XX en pouco máis dunha ducia de veces (NTLLE). De feito, na súa busca o dicionario da Academia remite á forma yerbal, que define como "terreno cubierto de hierbas" e como palabra extrapeninsular, específica de Cuba, México e a República Dominicana; o castelán de Bolivia sería o único en usar hierbal para esa acepción (Real Academia Española 2018), o que coincide coa acepción de herbal do dicionario RAG. Polo tanto, trátase como mínimo dun galeguismo léxico (xa que o que se fai é transferir para o castelán unha voz galega, herbal, que no primeiro non existía).

$\S$ jiestales (1): IB: 119v. / jiestar (3): IB: $122 \mathrm{v}$, $123 \mathrm{r}, 123 \mathrm{v}$.

Estas voces son substantivos de significación colectiva, neste caso vexetais, que polo tanto fan referencia a un conxunto de jiestas a través da sufixación substantival mediante o sufixo latino -ALE ou -ARE (Ferreiro 2001: 161-163). Polo tanto, a súa catalogación como galeguismo parte do substantivo orixinal, jiesta, do que non hai constancia en ningunha obra lexicográfica do castelán (histórica ou actual), nin dese xeito escrita nin con variantes gráficas (NTLLE); tampouco a hai a nivel literario (CORDE). É un calco moi claro, apoiado nunha acomodación fonética con ditongación incluída, da voz galega xesta, procedente do latín GENESTA (Ferreiro 1999: 86) e que á súa vez en castelán dá iniesta; esta voz, como explica o dicionario da Real Academia Española (2018), está en desuso e remite ao sinónimo retama. Esa é a mesma percepción do escribán de IC, xa que na totalidade das veces que fai uso de jiestal ou jiestar preocúpase de acompañala da aclaración "o retama(r)". Non queda claro se o escribán cría na validez de jiestarl 
jiestal como voz castelá e plenamente válida como sinónimo de retama ou se a introduce á mantenta, quizais para evitar unha palabra total ou amplamente descoñecida en Galiza ${ }^{14}$ e por iso a acompañaría, sendo así, da palabra real e correcta do castelán. En calquera caso e sexa como for, jiestal ou jiestar, mesmo jestal (IL: 472r) son invencións léxicas consistentes en acomodar foneticamente ao castelán a raíz galega xest- e engadirlle o sufixo abundancial -al ou -ar.

Por outro lado, o sufixo do substantivo colectivo en -al ou en - ar non ten maior transcendencia, xa que o propio Ferreiro (2001) deixa clara a orixe latina desa flutuación e Menéndez Pidal (1985: 168, 181-182, 199) confirma para o castelán o mesmo fenómeno flutuante que cataloga como "dismilación" ou "equivalencia acústica R = L"; tamén Pharies (2002: 92) puntualiza que "-ĀRIS funciona en latín como variante de -ĀLIS, y hasta cierto punto esp[añol] - ar sigue siendo, si no variante, prácticamente equiparable a - $a l$ " e recolle, como consecuencia diso, "numerosos dobletes en -al/-ar (...) a lo largo de la historia de la lengua, cf. manzanar [954] / mançanal 'manzanal [1495]" etc. De aí a vacilación do escribán entre a forma en -al e a forma en -ar. Por ese mesmo motivo descartamos como galeguismos as voces tojar (3 veces: IB: $119 \mathrm{v}, 123 \mathrm{r}$ ) ou tojal (7 veces en IC e 1 en IB), xa que, se ben non hai constancia de tojar en ningún dicionario da época nin actual, si o hai de tojal, ben documentado a nivel léxicográfico desde o século XIX e no dicionario RAE actual, así como de tojo (31 veces entre 1817 e 1992, segundo NTLLE).

§ jubenco/a (9): IC: 495r, 495v; REcl: 22v; IB: $128 \mathrm{v}, 129 \mathrm{r}, 130 \mathrm{v}$.

Malia que aparece unhas 27 veces nos dicionarios de castelán (1803-1992) e que os resultados máis achegados no tempo o cualifiquen como voz antiga, achamos esta forma (que concorre nos nosos textos grafada sempre con $<\mathrm{b}>$ ) un galeguismo léxico: vid. subenca.

$\S$ lagueiros (6): IC: 484r; IL: 473r; IB: 121r, $124 \mathrm{r}, 125 \mathrm{v}$.
Segundo Castaño Álvarez (2015), o lagueiro é unha medida galega derivada da cultura do liño en Galiza, como tamén testemuña Sarmiento (1970). Ningún manual lexicográfico castelán recolle a palabra (NTLLE) e tampouco sae no dicionario RAE actual. Abonden eses datos, unidos á propia estrutura morfolóxica da palabra (ditongo -ei-, impropio do castelán patrimonial) para catalogala como galeguismo léxico.

§ mesmo/a (2): IL: 472v, 482r.

Convive no mesmo documento con mismo, que sae en 4 ocasións (IL: 471v, 481r, 482r, 483r). Antes de deixarnos levar polas formas actuais en galego e castelán para evitar precipitacións, comprobamos que mesmo aparece nada menos que 48 veces nos dicionarios de castelán entre 1495 e 1992 (NTLLE), cualificado a veces como voz antiga. Non necesariamente ha de ser considerado, pois, un galeguismo; en casos coma este, malia que a forma galega puido ser a causa da presenza da palabra no texto, é imposible determinar a causalidade pola que aparece. Polo tanto, coa debida cautela sospeitamos que a influencia do galego pode estar detrás da aparición desta forma.

§ miedra (1): IB: 129r.

Este substantivo non aparece en ningún dicionario de lingua española, nin historicamente (NTLLE) nin na actualidade (RAE), así como tampouco hai constancia da palabra en documentos en castelán (CORDE). O Dicionario de Dicionarios, pola contra, testemuña a presenza de medra(s) 15 veces nos dicionarios galegos. $\mathrm{O}$ dicionario da RAG, ademais, catalógaa como substantivo feminino e defínea como "acción e efecto de medrar". Así pois, este é un calco da voz galega medra(s), acomodado foneticamente á estrutura do castelán mediante a ditongación crecente, e un claro galeguismo léxico.

§ mijo grueso(1): IC: 490r. Vid. mijo menudo.

§ mijo menudo (25): IC: 483r, 483v, 484r, $484 \mathrm{v}, 485 \mathrm{v}, 488 \mathrm{v}, 489 \mathrm{r}, 489 \mathrm{v}, 490 \mathrm{r}, 490 \mathrm{v}$; REcl: 8r; IB: 120v, 121r, 121v, 124r, 125v.

14 Non se inclúe no dicionario actual da RAG e só aparece unha vez nunha obra lexicográfica, de Sarmiento, e non co significado exacto que tería nos nosos documentos (DdD); por outra parte, fronte ás 428 aparicións de xesta no TILG danse só 16 de retama (e, en 4 deses 16 casos, aparece para definir a entrada xesta nun manual sobre vexetais). 
A locución aparece case sempre nomeando un cereal en concorrencia con outros moitos, entre eles o maíz ( 23 veces en IC, 1 vez en REcl, 5 en IB). Como apunta Mariño Paz (1998: 288), “o castelán común aceptou plenamente a voz maíz e conservou o significado tradicional da palabra mijo" cando o primeiro chegou de América. Así o testemuña o CORDE: só unha ocorrencia da locución mijo menudo en textos casteláns. Non foi así no caso da lingua galega: como explica Álvarez (2002: 69-94), o grande éxito colleitado polo maíz americano acabou relegando a unha situación moi secundaria ou de inexistencia ao mijo menudo dentro da agricultura e alimentación galegas, a tal punto que este último acabou dando o seu nome orixinal, millo, ao chegado de América (maíz), con características morfolóxicas e nutritivas diferentes dentro da similitude entre ambos cereais. Deste xeito, o cereal máis antigo acabou tendo que incorporar o adxectivo miúdo (facendo referencia a un trazo da súa morfoloxía) para ser diferenciado do máis recente: millo fronte a millo miúdo ${ }^{15}$. Isto, como explicaba Mariño Paz e confirma o CORDE, non operou en castelán, onde se diferenciou maíz de mijo respectivamente. Nótese, pois, o ambiente galegofalante que rodea os escribáns dos documentos cando, non só nunca usan mijo sen acompañalo do adxectivo que deixe ben clara a diferenza de significado co millo galego, senón que ademais nun caso (IC: 489r) o escribán chega a denominar mijo maíz ao millo para xusto a continuación distinguilo do mijo menudo (millo miúdo) -se cadra por tratar de traducir literalmente millo e decatarse de que podería levar a confusión-, e noutra ocasión mijo grueso (IC: 490r), outra influencia do galego (non aparece en textos casteláns segundo CORDE) ao non necesitar o castelán unha locución así por ter xa a voz maíz e por existir tamén a voz millo gordo en galego.

Se procuramos a voz mijo no dicionario RAE máis próximo á época do catastro, o de 1734 (NTLLE) é moi rechamante observar que inclúe unha segunda acepción, distinta da principal, que reza "Lo mismo que Maíz: y assi se le llama en Galicia (...)" (RAE 1734). Así pois, en definitiva, encontramos a locución $m i$ jo menudo un galeguismo léxico presente en tres dos nosos documentos.
$\S$ naviza (1): IB: $121 \mathrm{r}$.

A palabra aparece 37 veces nos dicionarios de castelán só a partir de 1734 . Nese dicionario elaborado pola RAE dáse a seguinte definición: "Nabo pequeño y delgado que nace del nabo redondo, mui tierno y sabroso, y mui usado en Galicia con este nombre" (CORDE). Se sumamos a incorporación lexicográfica tardía no castelán ao contexto galegófono no que foron escritos os documentos catastrais, podemos suxerir que se trata dun galeguismo léxico.

§ pasal (1): IC: 481r.

A palabra só aparece historicamente 4 veces en dicionarios de castelán (NTLLE), todas elas desde mediados do século XIX, e só 7 no CORDE (curiosamente tamén desde mediados do XIX) como sinónimo de pasadera; non aparece no dicionario actual RAE. Pola contra, si aparece en RAG e nos dicionarios máis antigos de galego, ata un total de 12 veces (DdD), lembremos, nunha lingua cun acervo lexicográfico moito menor có do castelán. Estes datos, unidos ás contadas aparicións tardías no castelán, lévannos a pensar que se trata dun galeguismo léxico e que quizais fose unha forma de incorporación tardía ao castelán e que acabou por desaparecer.

$\S$ rego (14): (REcl: 11r, 11v, 12r, 16r, 17r, 17v, 19r, 19v, 20r, 24v).

Galeguismo léxico pleno (vid. riego).

\subsection{Galeguismos semánticos}

$\S$ corredera (2): IC: 479v, 481v.

Malia que algúns dicionarios galego-castelán non actuais traducen a palabra galega corredoira na súa única acepción de "camiño de carros" (RAG) como corredera (o Dicionario de Dicionarios amosa Cuveiro Piñol e Filgueira Valverde et alii), en ningún dicionario castelán da época, nin no actual (RAE) corredera aparece con ese significado. A acepción máis achegada, maiormente a principal nos dicionarios modernos (NTLLE), era a de "sitio o lugar destinado para correr caballos" (RAE) ou similar. Non obstante, non temos constancia de que existise nin exista un lugar desas características e con esa finalidade dentro da gandería equina galega, e moito menos unha palabra que a designe, 
como pode comprobarse en Groba Bouza e Vázquez Corral (2016: 79-112) ou IES Terra de Turonio (2009), principais compiladores de léxico e vocabulario galego relacionado co mundo cabalar e que proporcionan, nomeadamente no caso dos primeiros, definicións ben exactas. Ao noso xuízo, o feito de que Cuveiro Piñol ou Filgueira Valverde et alii traduzan corredoira por corredera vén demostrar, precisamente, que a palabra corredera podía operar, xa en séculos pasados, como calco que tentase traducir (deficientemente e sen correlación léxica e semántica co castelán) unha palabra cunha morfoloxía galega de seu moi distante da do castelán. Repárese, ademais, na operatividade e validez que ten a tradución de palabras co sufixo galego -oira/o ao castelán -era/o (como en lavadoiro : lavadero), o que conduciría, tanto aos referidos lexicógrafos como ao escribán de IC, a calcar o devandito esquema de tradución a todas luces de xeito equivocado. Ademais, nas dúas ocasións onde se cita a palabra o escribán está describindo os límites xeográficos de dúas freguesías, San Salvador da Baña e Santa María de Portor, achegando elementos físicos (ríos, penas, devesas etc. con cadanseu microtopónimo) que as delimitaban, o que casa mellor coa idea de corredoiras na súa definición RAG con cadanseu microtopónimo, Mosteiros e Longráns, e non con supostos lugares onde correrían cabalos (o cal suscitaría tamén a interrogante sobre a súa propiedade e o seu nome, en caso de que fosen particulares). Así, coidamos que corredera supón un galeguismo semántico no noso texto.

§ riego (8): IC: $479 \mathrm{r}, 479 \mathrm{v}, 480 \mathrm{v}$; $\mathrm{REcl}: 17 \mathrm{v}$, $18 \mathrm{r}, 19 \mathrm{v}, 20 \mathrm{r}, 25 \mathrm{v}$.

En ningún dicionario de castelán da época, nin anterior nin posterior (NTLLE), aparece riego como "pequeno suco natural polo que corre a auga" (dicionario RAG, que é o significado que suxire o contexto de todas as ocorrencias), nin sequera na actualidade, só como "acción y efecto de regar" ou similar (dicionario RAE). Polo tanto ha de ser considerado un galeguismo semántico adaptado graficamente á fonética do castelán mediante a ditongación. Isto vese confirmado coa convivencia coa forma léxica plena rego en REcl en 14 ocasións (REcl: $11 \mathrm{r}, 11 \mathrm{v}$, 12r, 16r, 17r, 17v, 19r, 19v, 20r, 24v).

\section{Conclusións}

En definitiva, o repaso polos galeguismos dos textos a través deste glosario de voces galegas amosa nada menos que 57 galeguismos (32 fonéticos, 19 léxicos, 3 morfolóxicos, 2 semánticos e 2 sintácticos), o que, de primeiras, constitúe unha cifra o suficientemente significativa como para que sexa razoable, cando menos, reparar no catastro de Ensenada como fonte documental para investigar o galego da Idade Moderna e reclamar un uso que ata o día de hoxe non ten nas pescudas de lingüística histórica. De feito, a fonte tamén demostra ser valiosa para os estudos históricos do castelán de Galiza. Recuperando o título deste traballo, a voz subenca exemplifica a un tempo o léxico patrimonial conservado nesta altura fronte ao castelán e os fenómenos fonéticos autóctonos cos que contaba a nosa lingua nun momento no que a produción escrita na mesma se reducira drasticamente; do mesmo xeito, unha estrutura como ba fenecer achega información sobre a sintaxe galega desa época en contraposición á do castelán.

Fenómenos palpables como o seseo ou a despalatalización son útiles tamén para a dialectoloxía con perspectiva histórica; os fenómenos morfolóxicos reafirman a galeguidade e supervivencia dalgunhas flexións ou modificacións fonéticas nesa altura do século XVIII malia "as difíceis condicións sociolingüísticas padecidas pola nosa lingua desde o derradeiro período medieval" (Ferreiro 1999: 240). Os galeguismos léxicos, por exemplo estrigas, advirten da habilitación, ou como mínimo da conservación no galego da época ${ }^{16}$, de léxico adaptado á nosa realidade social, xeográfica e económica que incluso facía desprazar dun documento redactado en castelán as formas homólogas do castelán, de habelas. Así, os agra, conca, estriga, ferrado, lagueiro... están informando dunha realidade que os escribáns son incapaces de traducir a unha lingua que carece desas realidades xeográficas, económicas, etnográficas, culturais ou agrarias. Pola súa parte, a aparición sistemática e repetitiva, nestes documentos, da voz feligresía e da oración tiene en su compañía [nome propio] xogan incluso un papel relevante no debate normativo ${ }^{16}$; feligresía é un testemuño do viva que estaba a palabra freguesía na Galiza do XVIII opóndose a parroquia, mentres a estrutura de CD 
humano sen proposición engade máis exemplos á súa presenza no século XVIII ${ }^{17}$, testemuñando o seu carácter autóctono e enraizado como forma viva no país.

Fica bastante claro que, na maioría dos casos, non é intención dos escribáns que redactan os documentos introducir deliberadamente palabras galegas nos mesmos. Malia figuraren involuntariamente por parte dos escribentes, contribúen a asentar a idea dunha Galiza rural galegofalante en réxime case por completo monolingüe nesta altura do século XVIII e a ofrecer nocións simples de dialectoloxía da comarca da Barcala nese século. Certamente son contadas as veces nas que os redactores introducen palabras galegas de xeito voluntario e intencionado, e en todas elas fano por pura necesidade: ao non ser o castelán a lingua propia do país, en ocasións non lles abonda para dar conta de realidades galegas inexistentes alá onde o castelán é lingua do pobo e non lles queda máis remedio que botar man das formas que nomean esas realidades. No resto dos casos, múltiples factores como a procedencia do escribán e a súa formación, pero, sobre todo, o contexto que os rodea e os veciños (peritos) galegofalantes que os acompañan provocan interferencias, galeguismos fonéticos, semánticos, léxicos etc. que sen dúbida terían evitado de seren conscientes da forma correcta do castelán ou que por despiste ou celeridade non puideron evitar mesmo coñecéndoa. Este feito, de por si, é un bo indicativo da fiabilidade da fonte para o estudo do galego medio, pois os erros na redacción en castelán que axudan a botar un ollo sobre diferentes características do galego da época non son deliberados.

Todos estes trazos e o conxunto de galeguismos repasados fannos concluír, en definitiva, que o catastro de Ensenada é unha fonte documental efectiva e valiosa para a pescuda histórica da lingua galega no período da Idade Moderna e que, en diante, debería converterse nunha fonte da que botar man con sistematicidade para o labor en cuestión, malia o arduo labor que supoña a súa lectura e edición sosegada. A través desa premisa achegarémonos máis ás arelas da lingüística histórica galega de "seguir alumeando uns séculos que", se cadra, "xa non debe(re)mos seguir alcumando «escuros»" (Álvarez e González Seoane 2020: 8).

\section{Referencias bibliográficas}

ALGa = Instituto da Lingua Galega (2003): Atlas Lingüistico Galego. Vol. 3: Fonética. A Coruña: Fundación Pedro Barrié de la Maza.

Álvarez, Rosario (2002): "Viño novo en odres vellos: os nomes do millo", en Rosario Álvarez et al. (eds.): Dialectoloxía e léxico. Santiago de Compostela: Consello da Cultura Galega, pp. 69-94.

Álvarez, Rosario e Ernesto González Seoane (2020): “Limiar”, en Rosario Álvarez e Emilio González Seoane (eds.): Calen barbas, falen cartas. A escrita en galego na Idade Moderna. Santiago de Compostela: Consello da Cultura Galega, pp. 6-8, http://consellodacultura.gal/publicacion.php?id=4373.

Álvarez, Rosario e Xosé Xove (2004): “Un testamento do galo de 1786”, en Teresa Amado Rodríguez et al. (eds.): Iucundi acti labores. Estudios en homenaje a Dulce Estefanía Álvarez. Santiago de Compostela: Universidade de Santiago de Compostela, pp. 501-525.

Blanco, Pilar e María Xesús García (2007): Ferrol e A Graña en 1752. O Catastro do Marqués da Ensenada. Ferrol: Embora.

Calheiros, Antonio Almeida (2009): “A freguesía como unidade político-administrativa mínima en Portugal”, en Fernando García Pazos (coord.): A Parroquia en Galicia: pasado, presente e futuro. Santiago de Compostela: Xunta de Galicia, pp. 347-370.

Camarero Bullón, Concepción (2002): "El Catastro de Ensenada, 1749-1759: diez años de intenso trabajo y 80.000 volúmenes manuscritos", CT Catastro 46, pp. 61-88, http://www.catastro.meh.es/documentos/ publicaciones/ct/ct46/06.\%20Concepcion\%20Camarero.pdf.

Cano Aguilar, Rafael (2004): “Cambios en la fonología del español durante los siglos XVI y XVII”, en Rafael Cano Aguilar (coord.): Historia de la lengua española. Barcelona: Ariel, pp. 825-857.

17 Con respecto a freguesía, xa Varela Barreiro (2015: 149) chamara a atención sobre a súa secundarización "na elaboración do padrón actual", mentres no caso do CD humano sen preposición Freixeiro Mato (2006: 633) recomenda o seu uso, considerando a estrutura con preposición $a$ froito da presión do castelán, cousa coa que tamén concorda López Martínez (1993: 169).

18 Cf. López Martínez 1993: 140. 
Cardesín, José María (1992): Tierra, trabajo y reproducción social en una aldea gallega (siglos XVIII-XX): Muerte de unos, vida de otros. Madrid: Ministerio de Agricultura, Pesca y Alimentación.

Carrasco, Lorena e Gonzalo Navaza (2014): Toponimia do Val de Fragoso. 3. Beade. Vigo: Universidade de Vigo, https://www.uvigo.gal/sites/uvigo.gal/files/contents/paragraph-file/2018-10/Beade.pdf.

Castaño Álvarez, José (2015): El libro de los pesos y medidas. Madrid: Esfera de los libros.

$\mathrm{CE}=$ Davies, Mark: Corpus del Español, https://www.corpusdelespanol.org/xs.asp [consulta: 14/07/2020].

Cidrás Escáneo, Francisco A. (2006): "Sobre o uso da preposición a con OD en galego", Verba. Anuario Galego de Filoloxía 33, pp. 147-174.

CORDE = Real Academia Española: Banco de datos (en liña). Corpus diacrónico del español, http://www. rae.es [consulta: 27/03/2020].

Corominas, Joan e José A. Pascual (1981): Diccionario crítico etimológico castellano e hispánico. Vol. 4. Madrid: Gredos.

(1983): Diccionario crítico etimológico castellano e hispánico. Vol. 5. Madrid: Gredos.

(1996): Diccionario crítico etimológico castellano e hispánico. Vol. 2. Madrid: Gredos.

DdD = Santamarina, Antón (2003): Dicionario de dicionarios da lingua galega . A Coruña: Fundación Pedro Barrié de la Maza, http://sli.uvigo.es/DdD/ [consulta: 11/02/2020].

Fernández Díaz, Roberto (1993): Manual de Historia de España: la España Moderna, siglo XVIII. Madrid: Cambio 16.

Fernández Martín, Patricia (2018): Perifrasis verbales de infinitivo en el español áureo: entre las unidades fraseológicas y las estructuras disjuntas. Madrid: Instituto Cervantes, https://cvc.cervantes.es/lengua/ biblioteca_fraseologica/n7_fernandez/.

Fernández Rei, Francisco (1990): Dialectoloxía da lingua galega. Vigo: Xerais.

Ferreiro, Manuel (1999): Gramática histórica galega. I. Fonética e morfosintaxe. Santiago de Compostela: Laiovento.

(2001): Gramática histórica galega. II. Lexicoloxía. Santiago de Compostela: Laiovento.

Flores Dávila, Rodrigo (2014): "La preposición a", en Concepción Company Company (dir.): Sintaxis histórica de la lengua española. Tercera parte. Adverbios, preposiciones y conjunciones. Relaciones interoracionales. México: Fondo de Cultura Económica / Universidad Nacional Autónoma de México, vol. 2, pp. 1195-1340.

Freixeiro Mato, Xosé Ramón (2006): Gramática da lingua galega. II. Morfosintaxe. Vigo: A Nosa Terra.

García Godoy, María Teresa (ed.) (2012): El español del siglo XVIII. Cambios diacrónicos en el primer español moderno. Bern: Peter Lang, DOI: https://doi.org/10.3726/978-3-0351-0388-5.

Girón Alconchel, José Luis (2004): "Cambios gramaticales en los Siglos de Oro”, en Rafael Cano Aguilar (dir.): Historia de la lengua española. Barcelona: Ariel, pp. 859-894.

Gómez Urdáñez, José Luís (1996): El proyecto reformista de Ensenada. Lleida: Milenio.

González Cruz, Isabel (1995): "Lengua, prestigio y prejuicios lingüísticos: Algunas consideraciones sobre el español", Revue belge de philologie et d'histoire 73/3, pp. 715-723, DOI: https://doi.org/10.3406/ rbph.1995.4032.

Gordón Peral, María Dolores (2001): "Las fuentes de documentación toponímica: el catastro del Marqués de la Ensenada y su interés lingüístico", en Elena Méndez García de Paredes, J. Mendoza e Yolanda Congosto Martín (coords.): Indagaciones sobre la lengua: estudios de filología y lingüística españolas en memoria de Emilio Alarcos. Sevilla: Universidad de Sevilla, pp. 437-454.

Groba Bouza, Fernando e Antón Vázquez Corral (2016): "Achegas para un dicionario equino galego", Madrygal. Revista de Estudios Gallegos 19, pp. 79-112, DOI: https://doi.org/10.5209/MADR.53991.

IES Terra de Turonio (2009): "Vocabulario de Ceibes no Monte", en Ceibes no monte. Gondomar: IEs Terra de Turonio, http://www.ceibesnomonte.com/vocabulario/a [consulta: 12/07/2020].

Laca, Brenda (2006): "El objeto directo. La marcación preposicional”, en Concepción Company Company (dir.): Sintaxis histórica de la lengua española. Primera parte. La frase verbal. México: Fondo de Cultura Económica / Universidad Nacional Autónoma de México, vol. 1, pp. 423-475.

López Alsina, Fernando (2009): "Da protoparroquia ou parroquia antiga altomedieval á parroquia clásica en Galicia", en Fernando García Pazos (coord.): A Parroquia en Galicia: pasado, presente e futuro. Santiago de Compostela: Xunta de Galicia, pp. 57-75.

López Martínez, Ma Sol (1993): O complemento directo con preposición a en galego (Anexo 36 de Verba. Anuario Galego de Filoloxía). Santiago de Compostela: Universidade de Santiago de Compostela.

Luis Pastor (2016): Luis Pastor, http://luispastor.es/ [consulta: 22/05/2020]. 
Marcos Martín, Alberto (2000): España en los siglos XVI, XVII y XVIII: economía y sociedad. Barcelona: Crítica.

Mariño Paz, Ramón (1998): Historia da lingua galega. Santiago de Compostela: Sotelo Blanco. (2003): O idioma galego no limiar da súa renacenza. A Coruña: Universidade da Coruña. (2017): Fonética e fonoloxía históricas da lingua galega. Vigo: Xerais.

Menéndez Pidal, Ramón (1985): Manual de gramática histórica española. Madrid: Espasa / Calpe.

Molina Díaz, Francisco de Asís (2006): "El Catastro de Ensenada como instrumento de investigación lingüística”, en Antonio Roldán Pérez et al. (eds.): Caminos actuales de la historiografia lingüística. Actas del V Congreso Internacional de la Sociedad Española de Historiografia Lingüística. Murcia: Universidad de Murcia, tomo 2, pp. 1153-1164.

Monteagudo, Henrique (1999): Historia social da lingua galega. Vigo: Galaxia.

- (2016): “A invención dos Séculos Escuros”, en Isidro Dubert (ed.): Historia das historias de Galicia. Vigo: Xerais, pp. 149-179.

(2020): "Panorama sociolingüístico de Galicia na Idade Moderna. O idioma galego durante os séculos XVI, XVII e XVIII”, en Rosario Álvarez e Ernesto González Seoane (eds.): Calen barbas, falen cartas. A escrita en galego na Idade Moderna. Santiago de Compostela: Consello da Cultura Galega, pp. $75-115$, http://consellodacultura.gal/publicacion.php?id=4373.

NTLLE = Real Academia Española: Nuevo Tesoro Léxicográfico de la Lengua Española, http://buscon.rae. es/ntlle/SrvltGUILoginNtlle [consulta: 10/04/2020].

PARES = Ministerio de Educación, Cultura y Deporte: PARES (Portal de Archivos Españoles), www.pares. mcu.es/Catastro/ [consulta: 23/05/2020].

Pharies, David (2002): Diccionario etimológico de los sufijos españoles. Madrid: Gredos.

Real Academia Española: Diccionario de la lengua española, 23ª ed. (versión 23.2 en liña), https://dle.rae.es [consulta: 12/06/2020].

Real Academia Galega: Dicionario da lingua galega (en liña), https://academia.gal/dicionario [consulta: 13/06/2020].

Río Barja, Francisco Xavier (1990): Cartografía xurisdiccional de Galicia no século XVIII. Santiago de Compostela: Consello da Cultura Galega.

Rodríguez Troncoso, Amador (2014): Os albores de Feiraco. Negreira: Feiraco.

Saavedra, Pegerto (2008): "La comercialización de las rentas agrarias en la Galicia del Antiguo Régimen", Obradoiro de historia moderna 17, pp. 245-275. https://dialnet.unirioja.es/servlet/articulo?codigo=2662071.

_ (2009): “A rede parroquial desde finais do século XV a mediados do XIX”, en Fernando García Pazos (coord.): A Parroquia en Galicia: pasado, presente e futuro. Santiago de Compostela: Xunta de Galicia, pp. 75-104.

(2011): "El Catastro de Ensenada en Galicia: tierras menguantes, ganados bastantes, vecinos sobrantes", en Alberto Marcos Martín (ed.): Hacer historia desde Simancas. Homenaje a José Luís Rodríguez de Diego. Valladolid: Junta de Castilla y León, pp. 685-704.

Sarmiento, Martín (1970): Colección de voces y frases gallegas (Edición de José Luis Pensado). Salamanca: Universidad de Salamanca.

Tabernero, Cristina; Ricardo Pichel e Andrés Enrique-Arias (2020): "El español en contacto con otras lenguas peninsulares”, Estudios de Lingüistica del Español 42, pp. 177-217, https://raco.cat/index.php/ Elies/article/view/384898.

TILG = Santamarina, Antón (dir.); Ernesto González Seoane e María Álvarez de la Granja: Tesouro informatizado da lingua galega (Versión 4.1 en liña). Santiago de Compostela: Instituto da Lingua Galega, http://ilg.usc.es/TILG/ [consulta: 12/03/2020].

TMILG = Varela Barreiro, Xavier (dir.) (2004-): Tesouro Medieval Informatizado da Lingua Galega. Santiago de Compostela: Instituto da Lingua Galega, http://ilg.usc.es/tmilg [consulta: 18/06/2020].

Torres Luna, María Pilar de e Rubén C. Lois González (2009): "A parroquia e a xeografía de Galicia”, en Fernando García Pazos (coord.): A Parroquia en Galicia: pasado, presente e futuro. Santiago de Compostela: Xunta de Galicia, pp. 21-54.

Varela Barreiro, Xavier (2015): "Freguesía e parroquia. Dúas voces que reclaman un dicionario histórico para a lingua galega", en Ramón Mariño Paz e Xavier Varela Barreiro (eds.): Lingüistica histórica e edición de textos galegos medievais (Anexo 73 de Verba. Anuario Galego de Filoloxía). Santiago de Compostela: Universidade de Santiago de Compostela, pp. 147-175. 
Vidal Fonseca, Guillermo (2016): "La antroponimia de la comarca de Barcala (Galicia): evolución histórica moderna y causas implicadas”, Estudios interlingüisticos 4, pp. 99-117, https://estudiosinterlinguisticos.files.wordpress.com/2016/12/04vidalfonseca.pdf.

(2020): O Val de Barcala e as súas bases lingüísticas galegas no Catastro de Ensenada (século XVIII). Tese de doutoramento inédita. Santiago de Compostela: Universidade de Santiago de Compostela.

Yllera, Alicia (1980): Sintaxis histórica del verbo español: las perífrasis medievales. Zaragoza: Universidad de Zaragoza.

Xunta de Galicia: Tradutor Gaio, http://tradutorgaio.xunta.gal/TradutorPublico/traducir/index [consulta: 19/01/2020]. 